\title{
LEVEL II SCOUR ANALYSIS FOR BRIDGE 4 (RYEGTH00050004) on TOWN HIGHWAY 5, crossing the WELLS RIVER, RYEGATE, VERMONT
}

Open-File Report 97-765

Prepared in cooperation with

VERMONT AGENCY OF TRANSPORTATION and

FEDERAL HIGHWAY ADMINISTRATION

U.S. Department of the Interior U.S. Geological Survey

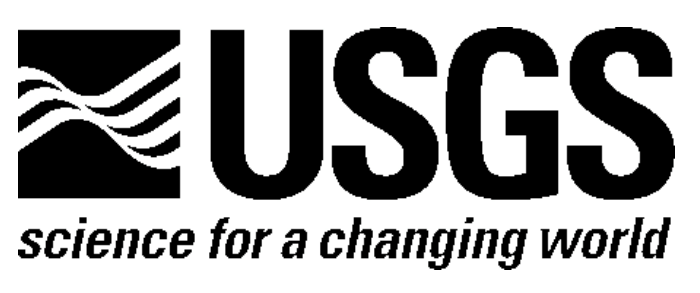




\section{LEVEL II SCOUR ANALYSIS FOR BRIDGE 4 (RYEGTH00050004) on TOWN HIGHWAY 5, crossing the WELLS RIVER, RYEGATE, VERMONT}

By MICHAEL A. IVANOFF AND ROBERT E. HAMMOND

U.S. Geological Survey Open-File Report 97-765

Prepared in cooperation with

VERMONT AGENCY OF TRANSPORTATION

and

FEDERAL HIGHWAY ADMINISTRATION 


\title{
U.S. DEPARTMENT OF THE INTERIOR BRUCE BABBITT, Secretary
}

\author{
U.S. GEOLOGICAL SURVEY \\ Mark Schaefer, Acting Director
}

For additional information write to:

District Chief

U.S. Geological Survey 361 Commerce Way

Pembroke, NH 03275-3718
Copies of this report may be purchased from:

U.S. Geological Survey

Branch of Information Services

Open-File Reports Unit

Box 25286

Denver, CO 80225-0286 


\section{CONTENTS}

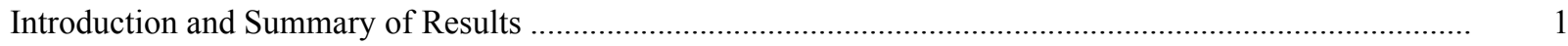

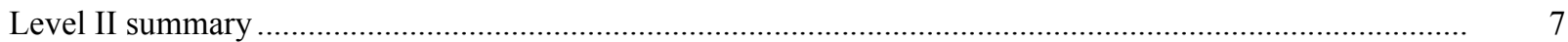

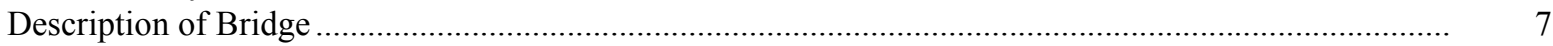

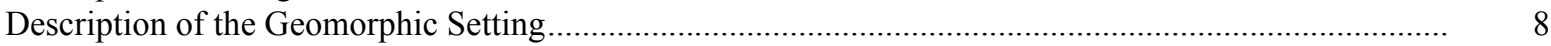

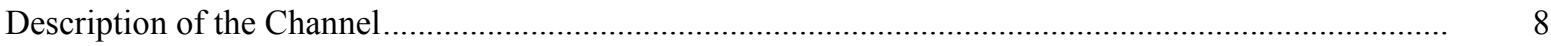

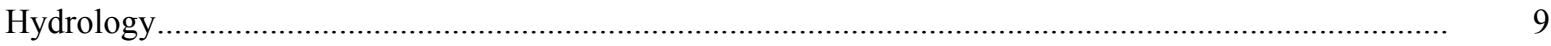

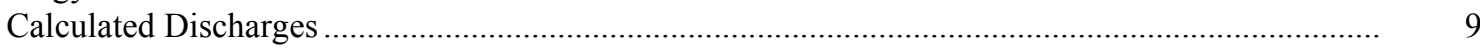

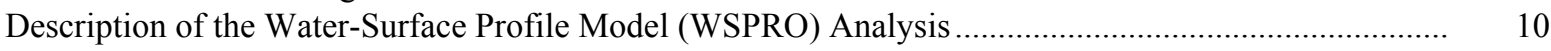

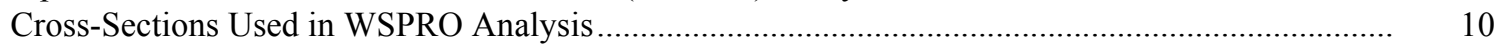

Data and Assumptions Used in WSPRO Model ...................................................................... 11

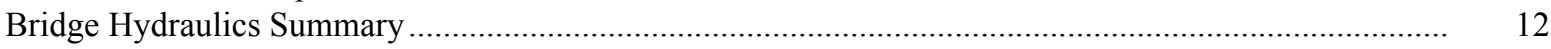

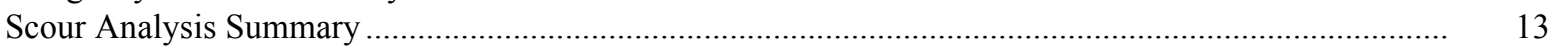

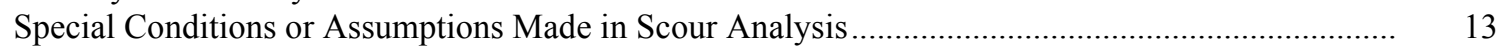

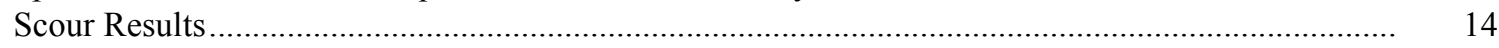

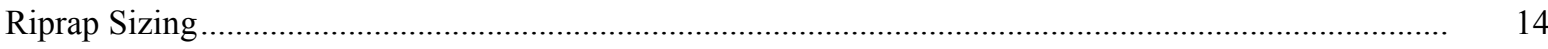

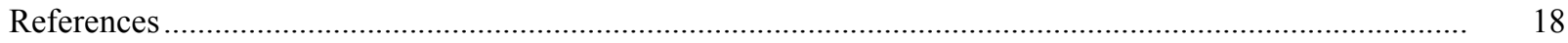

Appendixes:

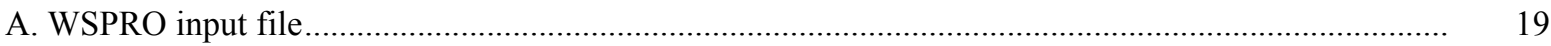

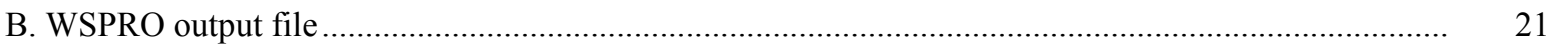

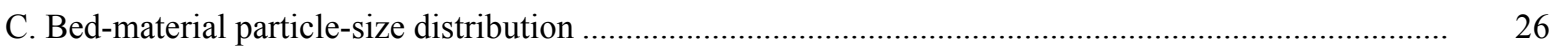

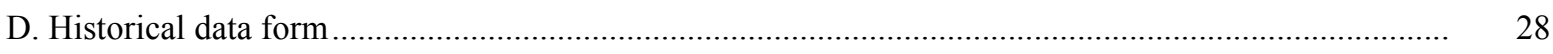

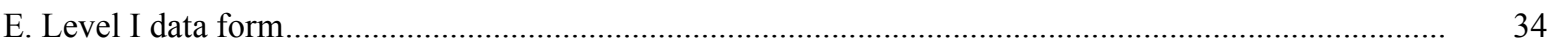

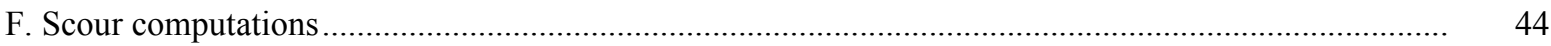

\section{FIGURES}

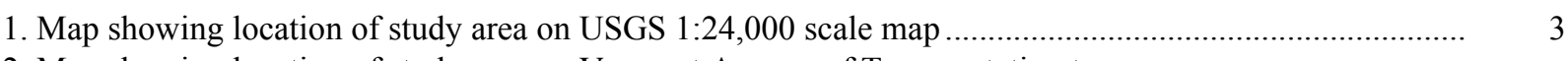

2. Map showing location of study area on Vermont Agency of Transportation town
highway map

3. Structure RYEGTH00050004 viewed from upstream (August 21, 1995) ............................................. 5

4. Downstream channel viewed from structure RYEGTH00050004 (August 21, 1995) ........................... 5

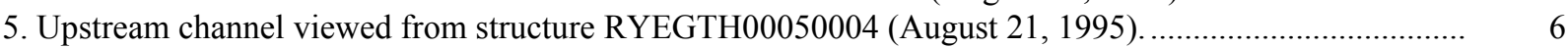

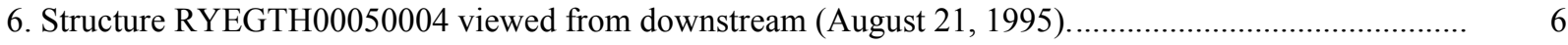

7. Water-surface profiles for the 100- and 500-year discharges at structure

RYEGTH00050004 on Town Highway 5, crossing the Wells River,

Ryegate, Vermont.

8. Scour elevations for the 100- and 500-year discharges at structure

RYEGTH00050004 on Town Highway 5, crossing the Wells River,

Ryegate, Vermont.

\section{TABLES}

1. Remaining footing/pile depth at abutments for the 100-year discharge at structure

RYEGTH00050004 on Town Highway 5, crossing the Wells River,

Ryegate, Vermont

2. Remaining footing/pile depth at abutments for the 500-year discharge at structure

RYEGTH00050004 on Town Highway 5, crossing the Wells River,

Ryegate, Vermont .

5
(5 


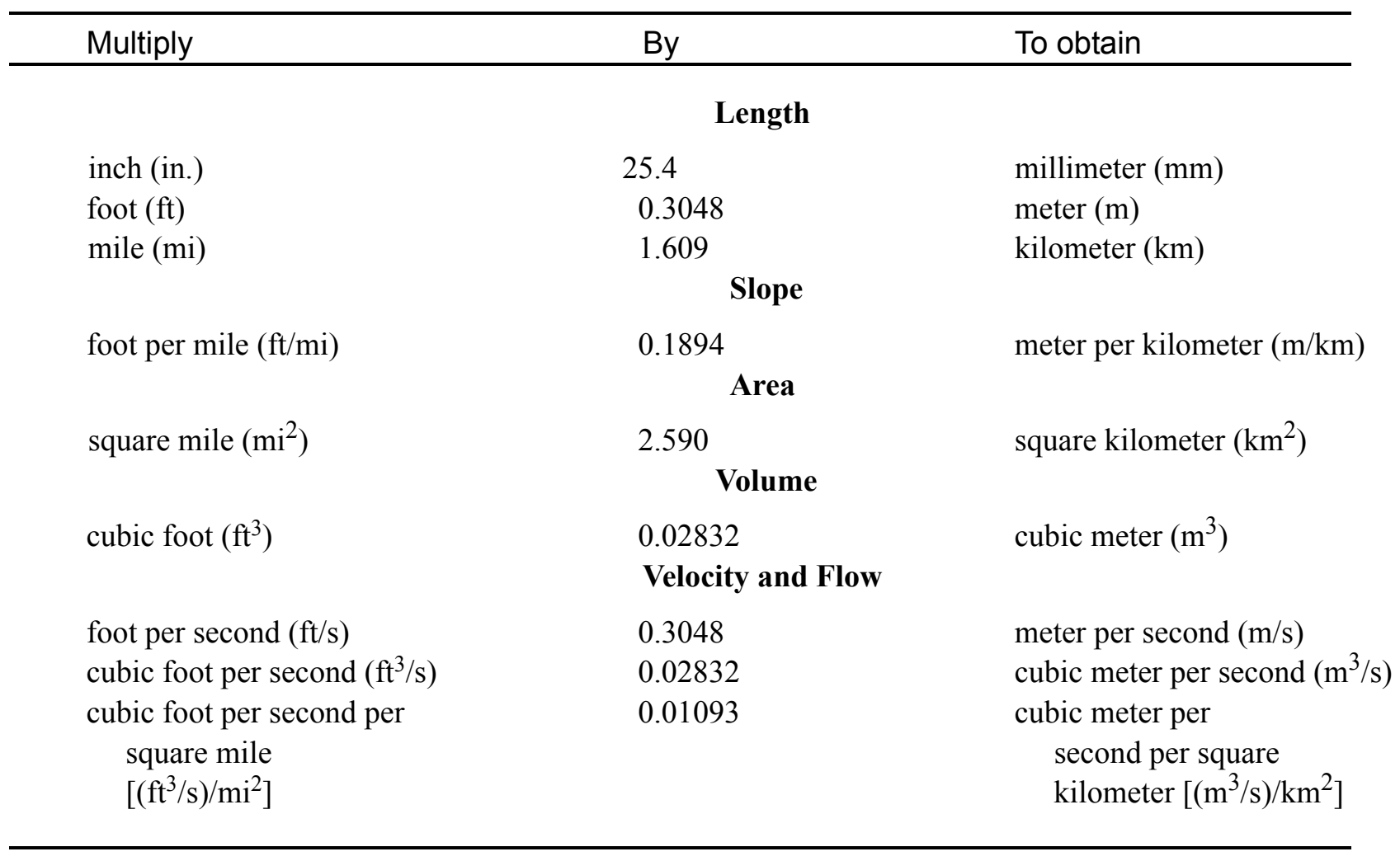

\section{OTHER ABBREVIATIONS}

$\begin{array}{lrlr}\mathrm{BF} & \text { bank full } & \text { LWW } & \text { left wingwall } \\ \mathrm{cfs} & \text { cubic feet per second } & \text { MC } & \text { main channel } \\ \mathrm{D}_{50} & \text { median diameter of bed material } & \text { RAB } & \text { right abutment } \\ \mathrm{DS} & \text { downstream } & \text { RABUT } & \text { face of right abutment } \\ \mathrm{elev} & \text { elevation } & \text { RB } & \text { right bank } \\ \mathrm{f} / \mathrm{p} & \text { flood plain } & \text { ROB } & \text { right overbank } \\ \mathrm{ft}^{2} & \text { square feet } & \text { RWW } & \text { right wingwall } \\ \mathrm{ft} / \mathrm{ft} & \text { feet per foot } & \text { TH } & \text { town highway } \\ \mathrm{JCT} & \text { junction } & \text { UB } & \text { under bridge } \\ \mathrm{LAB} & \text { left abutment } & \text { US } & \text { upstream } \\ \mathrm{LABUT} & \text { face of left abutment } & \text { USGS } & \text { United States Geological Survey } \\ \mathrm{LB} & \text { left bank } & \text { VTAOT Vermont Agency of Transportation } \\ \mathrm{LOB} & \text { left overbank } & \text { WSPRO } & \text { water-surface profile model }\end{array}$

In this report, the words "right" and "left" refer to directions that would be reported by an observer facing downstream. Sea level: In this report, "sea level" refers to the National Geodetic Vertical Datum of 1929-- a geodetic datum derived from a general adjustment of the first-order level nets of the United States and Canada, formerly called Sea Level Datum of 1929.

In the appendices, the above abbreviations may be combined. For example, USLB would represent upstream left bank. 


\title{
LEVEL II SCOUR ANALYSIS FOR BRIDGE 4 (RYEGTH00050004) ON TOWN HIGHWAY 5, CROSSING THE WELLS RIVER, RYEGATE, VERMONT
}

\author{
By Michael A. Ivanoff and Robert E. Hammond
}

\section{INTRODUCTION AND SUMMARY OF RESULTS}

This report provides the results of a detailed Level II analysis of scour potential at structure RYEGTH00050004 on Town Highway 5 crossing the Wells River, Ryegate, Vermont (figures 1-8). A Level II study is a basic engineering analysis of the site, including a quantitative analysis of stream stability and scour (U.S. Department of Transportation, 1993). Results of a Level I scour investigation also are included in Appendix E of this report. A Level I investigation provides a qualitative geomorphic characterization of the study site. Information on the bridge, gleaned from Vermont Agency of Transportation (VTAOT) files, was compiled prior to conducting Level I and Level II analyses and is found in Appendix D.

The site is in the New England Upland section of the New England physiographic province in eastern Vermont. The $84.7-\mathrm{mi}^{2}$ drainage area is in a predominantly rural and forested basin. In the vicinity of the study site, the surface cover includes shrubs and brush on the upstream left bank and downstream right bank of the bridge. The upstream right bank and downstream left bank of the bridge is forested.

In the study area, the Wells River has an incised, sinuous channel with a slope of approximately $0.008 \mathrm{ft} / \mathrm{ft}$, an average channel top width of $107 \mathrm{ft}$ and an average bank height of $11 \mathrm{ft}$. The channel bed material ranges from gravel to boulder with a median grain size $\left(\mathrm{D}_{50}\right)$ of $67.4 \mathrm{~mm}(0.221 \mathrm{ft})$. The geomorphic assessment at the time of the Level I and Level II site visit on August 21, 1995, indicated that the reach was laterally unstable with mass wasting along the upstream right bank.

The Town Highway 5 crossing of the Wells River is a 108-ft-long, two-lane bridge consisting of a 100-foot steel-beam span (Vermont Agency of Transportation, written communication, March 27, 1995). The opening length of the structure parallel to the bridge face is $93.4 \mathrm{ft}$. The bridge is supported by vertical, stone block abutments with wingwalls. The channel is skewed approximately 50 degrees to the opening while the opening-skew-toroadway is 45 degrees. 
The scour protection counter-measures at the site included type-1 stone fill (less than 12 inches diameter) along the downstream left road embankment. Also, type-2 stone fill (less than 36 inches diameter) along the upstream right wingwall, extending 30 feet upstream along the right bank, along the downstream end of the downstream right wingwall, along the downstream right road embankment, and along the downstream left bank below the old railroad bed. Additional details describing conditions at the site are included in the Level II Summary and Appendices D and E.

Scour depths and recommended rock rip-rap sizes were computed using the general guidelines described in Hydraulic Engineering Circular 18 (Richardson and others, 1995) for the 100- and 500-year discharges. Total scour at a highway crossing is comprised of three components: 1) long-term streambed degradation; 2) contraction scour (due to accelerated flow caused by a reduction in flow area at a bridge) and; 3 ) local scour (caused by accelerated flow around piers and abutments). Total scour is the sum of the three components. Equations are available to compute depths for contraction and local scour and a summary of the results of these computations follows.

Contraction scour for all modelled flows ranged from 1.8 to $2.6 \mathrm{ft}$. The worst-case contraction scour occurred at the 500-year discharge. Abutment scour ranged from 10.2 to $22.6 \mathrm{ft}$. The worst-case abutment scour occurred at the 500-year discharge. Additional information on scour depths and depths to armoring are included in the section titled "Scour Results". Scoured-streambed elevations, based on the calculated scour depths, are presented in tables 1 and 2. A cross-section of the scour computed at the bridge is presented in figure 8. Scour depths were calculated assuming an infinite depth of erosive material and a homogeneous particle-size distribution.

It is generally accepted that the Froehlich equation (abutment scour) gives "excessively conservative estimates of scour depths" (Richardson and others, 1995, p. 47). Usually, computed scour depths are evaluated in combination with other information including (but not limited to) historical performance during flood events, the geomorphic stability assessment, existing scour protection measures, and the results of the hydraulic analyses. Therefore, scour depths adopted by VTAOT may differ from the computed values documented herein. 


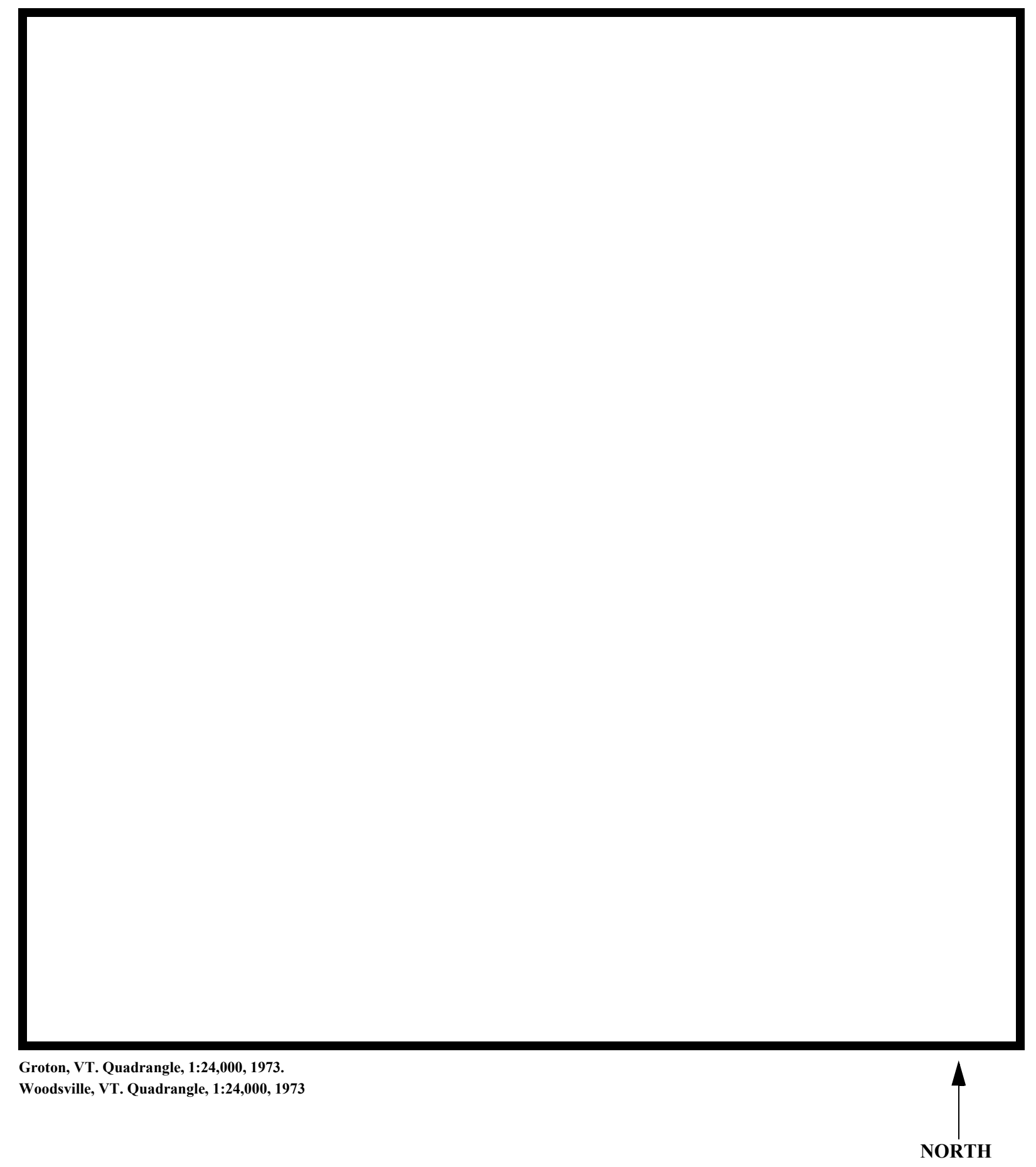

Figure 1. Location of study area on USGS 1:24,000 scale map. 
Figure 2. Location of study area on Vermont Agency of Transportation town highway map. 

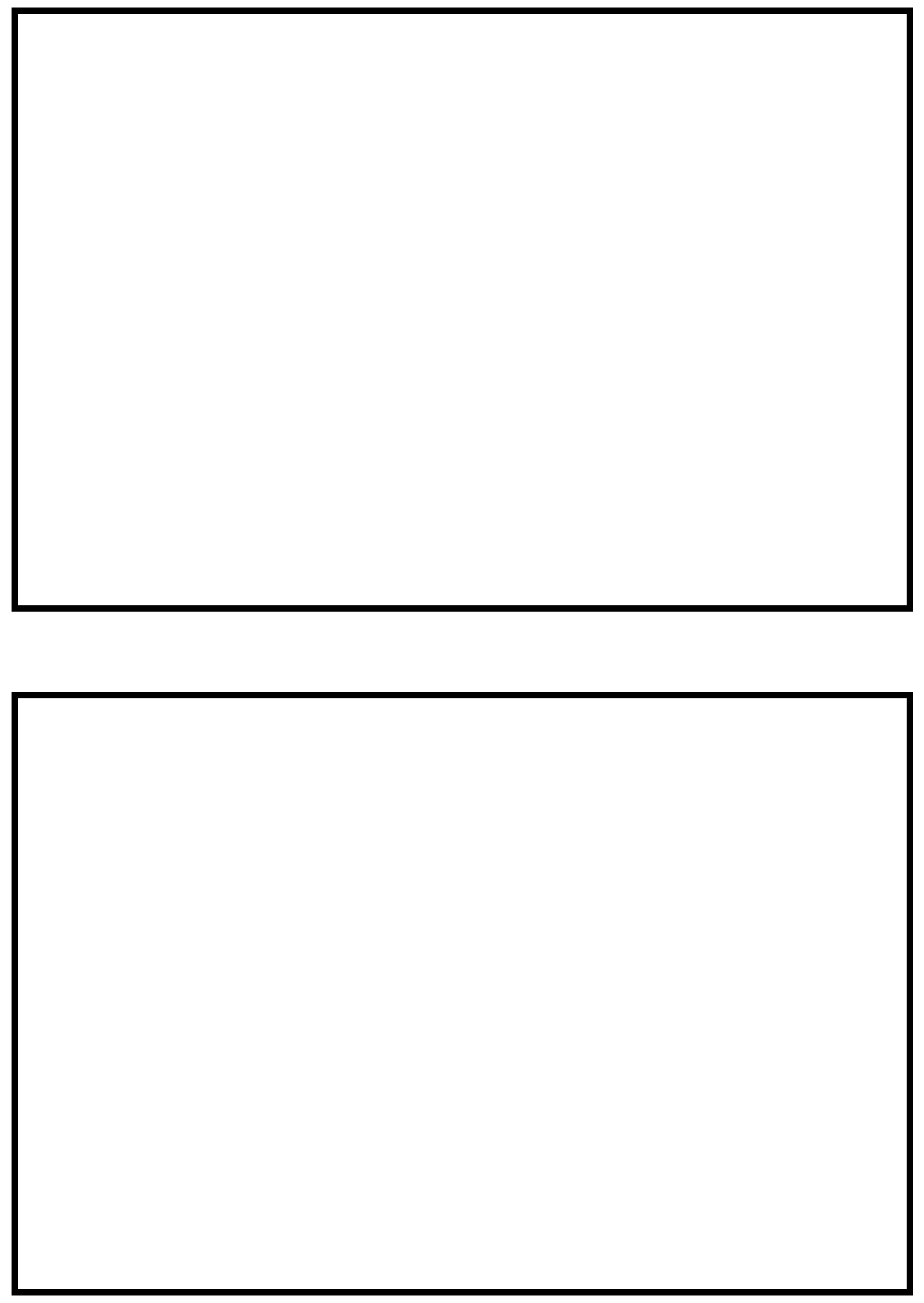

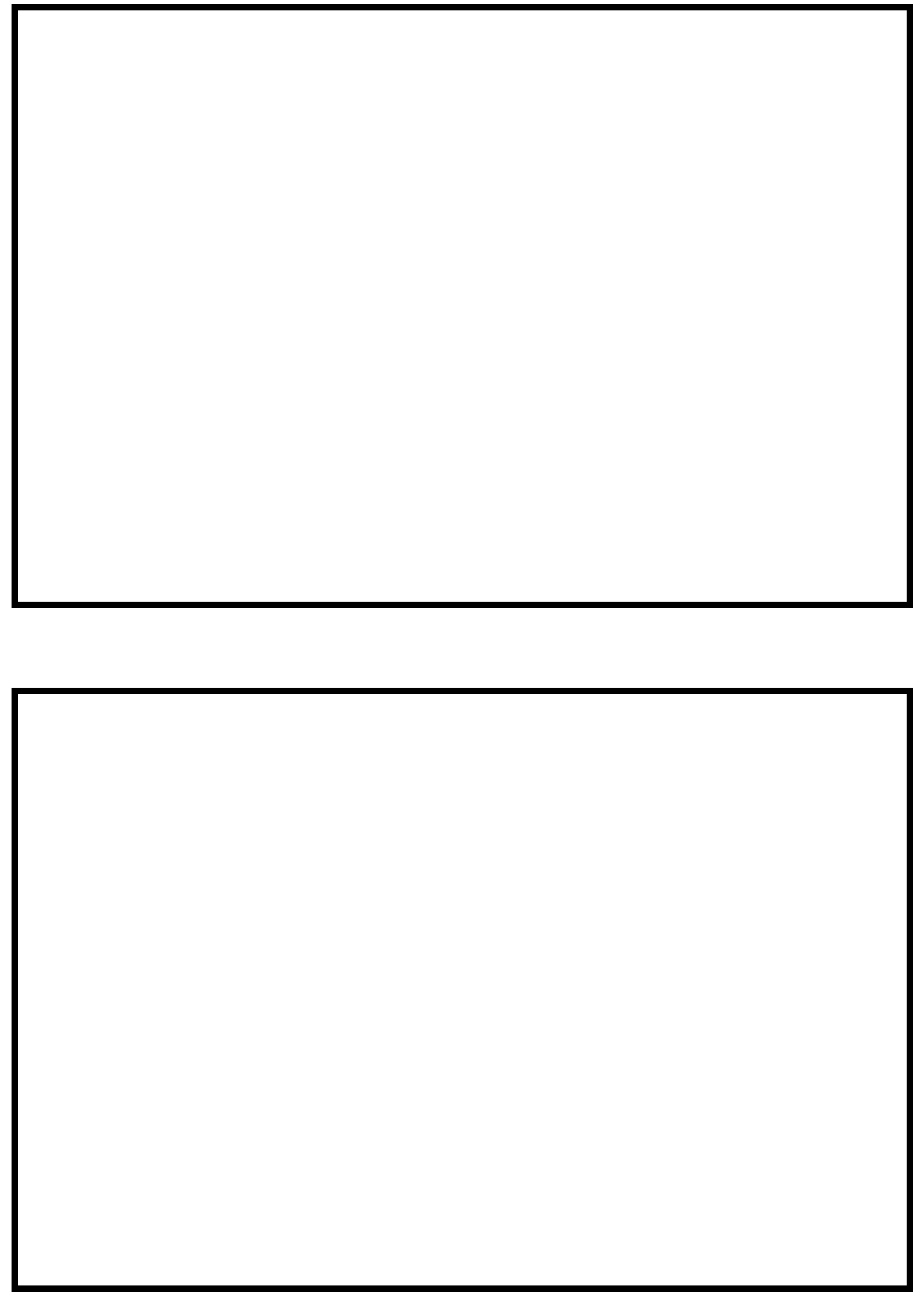


\section{LEVEL II SUMMARY}

\begin{tabular}{llllll} 
Structure Number & \multicolumn{2}{c}{ RYEGTH00050004 } & \multirow{2}{c}{ Wells River } & \\
Stream & & & \\
County & Caledonia & Road & TH 5 & District & 7
\end{tabular}

\section{Description of Bridge}

Bridge length $\frac{108}{} \boldsymbol{f t} \quad$ Bridge width $\frac{21.2}{f t \quad \text { Max span length } 100} \boldsymbol{f t}$ Alignment of bridge to road (on curve or straight)

Abutment type Vertical, stone blocks

Stone fill on abutment? No

\section{Embankment type} Straight, left; Curve, right

\section{Sloping} $8 / 21 / 95$
Dato af incnortion

Dasamintinu af otan sill Type-2, around the upstream right wingwall, the downstream end of the downstream right wingwall, and the downstream left bank.

Abutments and wingwalls are grouted stone blocks.

$\ldots \ldots$

Yes

50

No

Is bridge skewed to flood flow according to 'survey?

Angle

$8 / 21 / 95$

Debris accumulation on bridge at time of Level I or Level II site visit:

$$
\begin{gathered}
\text { Date af insnortion } \\
0
\end{gathered} \quad \begin{gathered}
\text { Percent of ahmmnal } \\
\text { blocked inortzontaty }
\end{gathered}
$$

\section{Percent of ahannol blocked nortzontatly}$$
95
$$

Level I

Level II streamward of the right abutment footing and upstream along the right cut bank.

Potential for debris
0
Low. There is some debris caught on old pilings three feet
Percent o: $8 / 21 /$ inel
blocked verticatty 0

A scour hole was observed on the streamward side of a few large boulders on the upstream right Doscriho anv fonturos noar ar at tho hridoo that mav, affort flow, (includo ahsorvation dato) bank as of $8 / 21 / 95$. 


\section{Description of the Geomorphic Setting}

General topography The channel is located within a moderate relief valley with a narrow flood plain and steep valley walls on both sides.

Geomorphic conditions at bridge site: downstream (DS), upstream (US)

Date of inspection $\quad 8 / 21 / 95$

DS left: $\quad$ Steep channel bank to a moderately sloped overbank.

DS right: $\quad$ Steep channel bank to a moderately sloped overbank.

US left: $\quad$ Steep channel bank to a narrow flood plain

US right: $\quad$ Steep valley wall

\section{Description of the Channel}

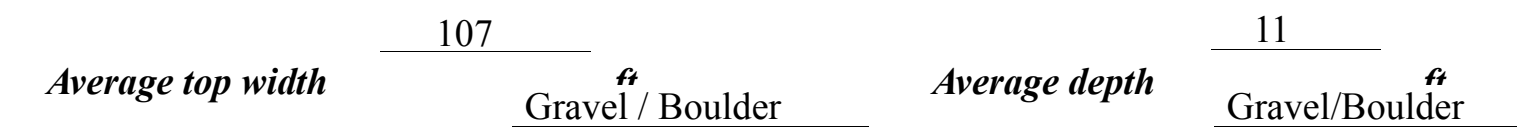

Predominant bed material

Bank material

Sinuous with semi-

alluvial channel boundaries and a narrow flood plain.

$8 / 21 / 95$

Vegetative co 1 Trees and brush.

DS left: $\quad$ Trees and brush.

DS right: $\quad$ Trees and brush with pasture on the flood plain.

US left: $\quad$ Trees and brush.

US right: $\quad$ No

Do banks appear stable? Severe fluvial erosion is occurring along the ypstream right bank.

date of observatton.

The assessment of

8/21/95 noted some

debris is caught on the boulders in the channel upstream.

Describe any obstructions in channel and date of observation. 


\title{
Hydrology
}

Drainage area $\quad 84.7 \boldsymbol{m i}^{2}$

Percentage of drainage area in physiographic provinces: (approximate)

Physiographic province/section New England/New England Upland
Percent of drainage area 100

\begin{abstract}
Is drainage area considered rural or urban?
Rural None urbanization:

Describe any significant
\end{abstract}

Yes

Is there a USGS gage on the stream of interest? Wells River at Wells River, VT USGS gage description 01139000

USGS gage number 98.4

Gage drainage area $m i^{2}$ No

Is there a lake/p -

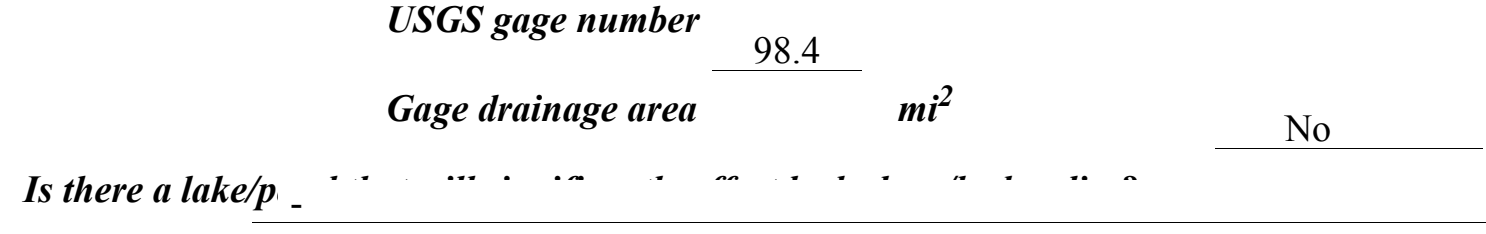

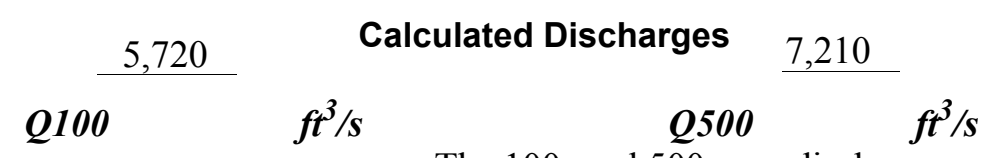

The 100- and 500-year discharges are based on a

drainage area relationship [(84.7/98.4)exp 0.7] with gage 01139000 at Wells River, VT. The 100and 500- year discharges at the gage were developed using a log-Pearson type-III analysis of annual peak-flow data (Interagency Advisory Committee on Water Data, 1982). These discharge values are within a range of several flood frequency curves based on empirical relationships for this site (Benson, 1962; Johnson and Tasker, 1974; FHWA, 1983; Potter, 1957a\&b; Talbot, 1887). 


\section{Description of the Water-Surface Profile Model (WSPRO) Analysis}

Datum for WSPRO analysis (USGS survey, sea level, VTAOT plans)

USGS survey

Datum tie between USGS survey and VTAOT plans

Subtract $595.9 \mathrm{ft}$ from the USGS

arbitrary survey datum to obtain VTAOT plans' datum. Subtract $0.4 \mathrm{ft}$ from the

USGS arbitrary survey datum to obtain National Geodetic Vertical Datum of 1929.

Description of reference marks used to determine USGS datum. $\quad$ RM1 is a USGS brass

tablet marked MR8-1933 on top of the downstream end of the right abutment (elev. $698.04 \mathrm{ft}$, arbitrary survey datum). RM2 is a chiseled X on top of the downstream end of the left abutment (elev. $699.36 \mathrm{ft}$, arbitrary survey datum).

\begin{tabular}{|c|c|c|c|}
\hline${ }^{1}$ Cross-section & $\begin{array}{c}\text { Section } \\
\text { Reference } \\
\text { Distance } \\
\text { (SRD) in feet }\end{array}$ & $\begin{array}{c}{ }^{2} \text { Cross-section } \\
\text { development }\end{array}$ & Comments \\
\hline EXITX & -94 & 1 & Exit section \\
\hline FULLV & 0 & 2 & $\begin{array}{l}\text { Downstream Full-valley } \\
\text { section (Templated from } \\
\text { EXITX) }\end{array}$ \\
\hline BRIDG & 0 & 1 & Bridge section \\
\hline RDWAY & 20 & 1 & Road Grade section \\
\hline APPRO & 109 & 1 & Approach section \\
\hline
\end{tabular}

${ }^{1}$ For location of cross-sections see plan-view sketch included with Level I field form, Appendix E. For more detail on how cross-sections were developed see WSPRO input file.

2 Cross-section development: (1) survey at SRD, (2) shift of survey data to SRD, (3) modification of survey data, (4) composite bridge section, (5) other. 


\section{Data and Assumptions Used in WSPRO Model}

Hydraulic analyses of the reach were done by use of the Federal Highway Administration's WSPRO step-backwater computer program (Shearman and others, 1986, and Shearman, 1990). The analyses reported herein reflect conditions existing at the site at the time of the study. Furthermore, in the development of the model it was necessary to assume no accumulation of debris or ice at the site. Results of the hydraulic model are presented in the Bridge Hydraulic Summary, Appendix B, and figure 7.

Channel roughness factors (Manning's “ $n$ ”) used in the hydraulic model were estimated using field inspections at each cross section following the general guidelines described by Arcement and Schneider (1989). Final adjustments to the values were made during the modelling of the reach. Channel " $\mathrm{n}$ " values for the reach ranged from 0.040 to 0.050 , and the overbank "n" value was 0.050 .

Normal depth at the exit section (EXITX) was assumed as the starting water surface. This depth was computed by use of the slope-conveyance method outlined in the user's manual for WSPRO (Shearman, 1990). The slope used was $0.008 \mathrm{ft} / \mathrm{ft}$, which was estimated from the topographic map (U.S. Geological Survey, 1988).

The approach section (APPRO) was surveyed one bridge length upstream of the upstream face as recommended by Shearman and others (1986). This location provides a consistent method for determining scour variables. 


\section{Bridge Hydraulics Summary}

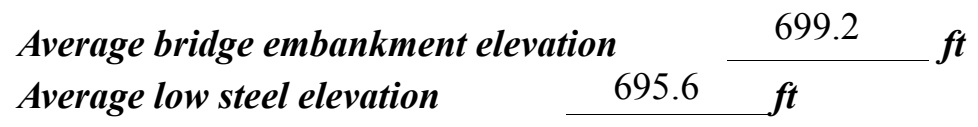

\begin{tabular}{|c|c|c|c|c|}
\hline 100-year discharge & 5,720 & $f t^{3} / s$ & & \\
\hline Water-surface eleva & n bridge & opening & 690.0 & $f t$ \\
\hline Road overtopping? & No & Discharge over $r$ & road & -- \\
\hline Area of flow in brid & $\overline{\text { ning }}$ & $425 \quad f t^{2}$ & & \\
\hline Average velocity in & openin & 13.5 & $f t / s$ & \\
\hline Maximum WSPRO & elocity & at bridge & 16.4 & $\mathrm{t} / \mathrm{s}$ \\
\hline
\end{tabular}

Water-surface elevation at Approach section with bridge 693.3 Water-surface elevation at Approach section without bridge 693.0 Amount of backwater caused by bridge

0.3 it

500-year discharge $\quad 7,210 \quad \mathrm{ft}^{3} / \mathrm{s}$

Water-surface elevation in bridge opening $690.9 f t$

Road overtopping? ___ No Discharge over road ___ -- ${ }_{-}^{3} .3 / \mathrm{s}$

Area of flow in bridge opening $\quad 485 \quad \mathrm{ft}^{2}$

Average velocity in bridge opening $14.9 \mathrm{ft} / \mathrm{s}$

Maximum WSPRO tube velocity at bridge 18.1 , 's

Water-surface elevation at Approach section with bridge

Water-surface elevation at Approach section without bridge

Amount of backwater caused by bridge 0.4 , ${ }_{t}$

694.7

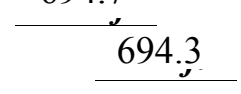

Incipient overtopping discharge ___ -- $\mathrm{ft}^{3} / \mathrm{s}$

Water-surface elevation in bridge opening $\quad--\quad$ it

Area of flow in bridge opening _ _ _- $\mathrm{ft}^{2}$

Average velocity in bridge opening $\quad--\quad f t / s$

Maximum WSPRO tube velocity at bridge _-- $f t / s$

Water-surface elevation at Approach section with bridge

Water-surface elevation at Approach section without bridge

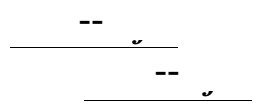
Amount of backwater caused by bridge _ 


\section{Scour Analysis Summary}

\section{Special Conditions or Assumptions Made in Scour Analysis}

Scour depths were computed using the general guidelines described in Hydraulic Engineering Circular 18 (Richardson and others, 1995). Scour depths were calculated assuming an infinite depth of erosive material and a homogeneous particle-size distribution. The results of the scour analysis are presented in tables 1 and 2 and a graph of the scour depths is presented in figure 8 .

Contraction scour was computed by use of the Laursen clear-water contraction scour equation (Richardson and others, 1995, p. 32, equation 20). The computed streambed armoring depths suggest that armoring will not limit the depth of contraction scour.

Abutment scour was computed by use of the Froehlich equation (Richardson and others, 1995, p. 48, equation 28). Variables for the Froehlich equation include the Froude number of the flow approaching the embankments, the length of the embankment blocking flow, and the depth of flow approaching the embankment less any roadway overtopping. 


\section{Scour Results}

100-yr discharge 500-yr discharge

Incipient

Contraction scour:

(Scour depths in feet)

Main channel

Live-bed scour

Clear-water scour

Depth to armoring

Left overbank

Right overbank

Local scour:

Abutment scour

Left abutment

10.2

11.8

20.6-

22.6-

Right abutment

Pier scour

Pier 1

Pier 2

Pier 3

Abutments:

Left abutment

Right abutment

Piers:

Pier 1

Pier 2

\section{Riprap Sizing}

overtopping

discharge

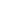




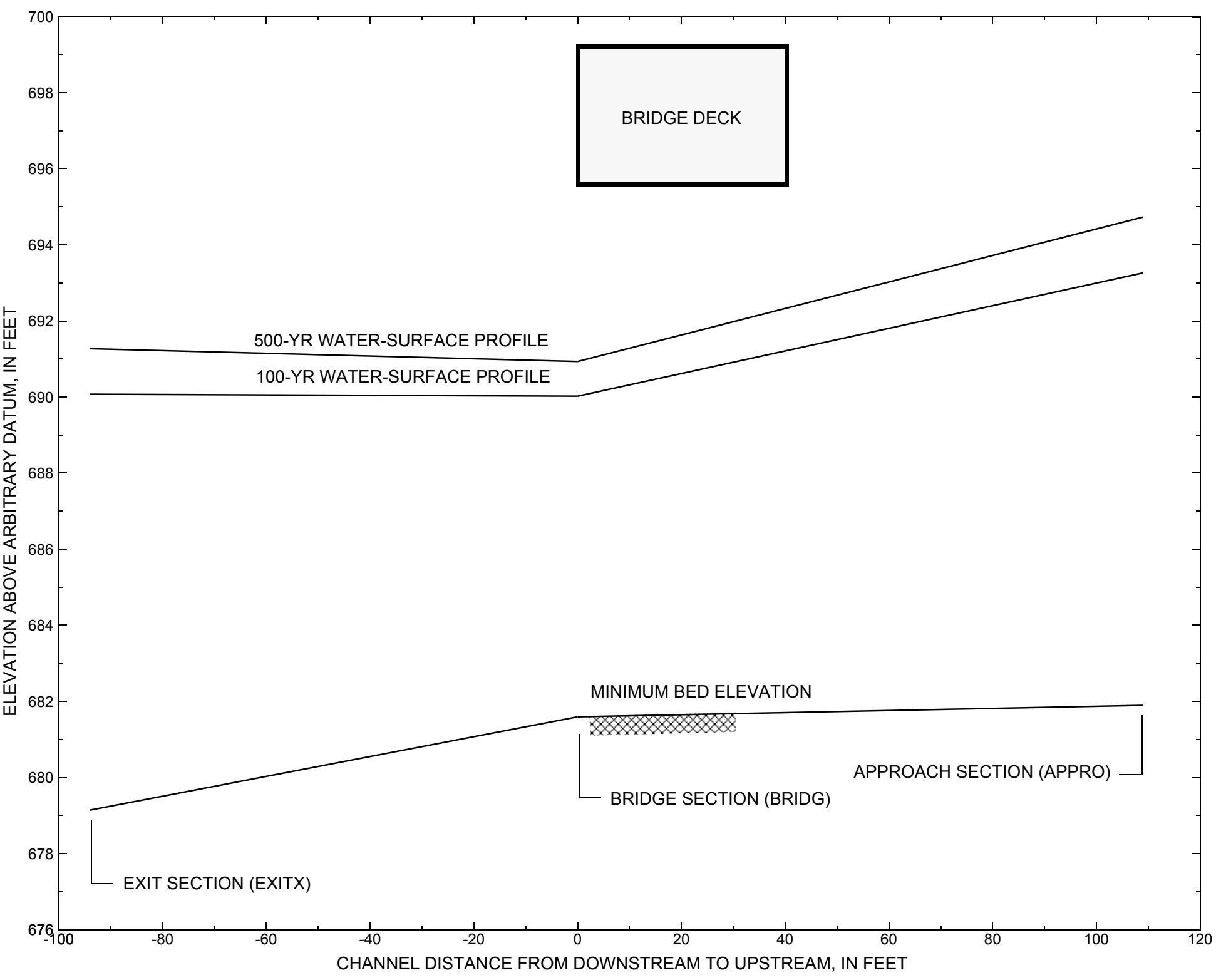

Figure 7. Water-surface profiles for the 100- and 500-yr discharges at structure RYEGTH00050004 on Town Highway 5, crossing the Wells River, Ryegate, Vermont. 


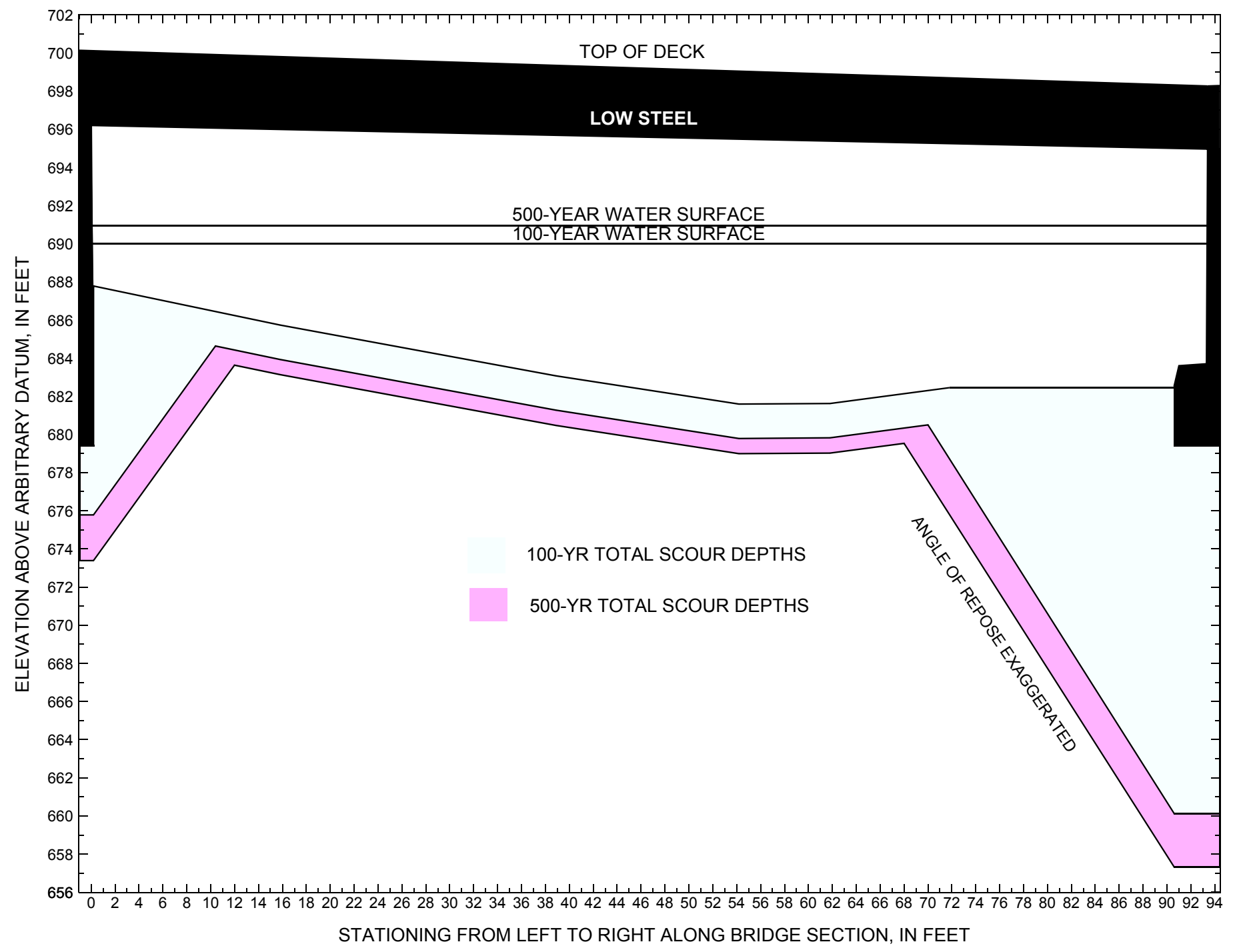

Figure 8. Scour elevations for the 100-yr and 500-yr discharges at structure RYEGTH00050004 on Town Highway 5, crossing the Wells River, Ryegate, Vermont. 
Table 1. Remaining footing/pile depth at abutments for the 100-year discharge at structure RYEGTH00050004 on Town Highway 5, crossing the Wells River, Ryegate, Vermont.

[VTAOT, Vermont Agency of Transportation; --,no data]

\begin{tabular}{|c|c|c|c|c|c|c|c|c|c|c|c|}
\hline Description & Station $^{1}$ & $\begin{array}{l}\text { VTAOT } \\
\text { minimum } \\
\text { bridge seat } \\
\text { elevation } \\
\text { (feet) }\end{array}$ & $\begin{array}{l}\text { Surveyed } \\
\text { minimum } \\
\text { low-chord } \\
\text { elevation }{ }^{2} \\
\text { (feet) }\end{array}$ & $\begin{array}{c}\text { Bottom of } \\
\text { footing/pile } \\
\text { elevation }{ }^{2} \\
\text { (feet) }\end{array}$ & $\begin{array}{c}\text { Channel } \\
\text { elevation at } \\
\text { abutment/ } \\
\text { pier }^{2} \\
\text { (feet) }\end{array}$ & $\begin{array}{l}\text { Contraction } \\
\text { scour depth } \\
\text { (feet) }\end{array}$ & $\begin{array}{l}\text { Abutment } \\
\text { scour } \\
\text { depth } \\
\text { (feet) }\end{array}$ & $\begin{array}{l}\text { Pier } \\
\text { scour } \\
\text { depth } \\
\text { (feet) }\end{array}$ & $\begin{array}{l}\text { Depth of } \\
\text { total scour } \\
\text { (feet) }\end{array}$ & $\begin{array}{c}\text { Elevation of } \\
\text { scour }^{2} \\
\text { (feet) }\end{array}$ & $\begin{array}{c}\text { Remaining } \\
\text { footing/pile } \\
\text { depth } \\
\text { (feet) }\end{array}$ \\
\hline \multicolumn{12}{|c|}{100 -yr. discharge is 5,720 cubic-feet per second } \\
\hline Left abutment & 0.0 & 98.6 & 696.2 & 679.4 & 687.8 & 1.8 & 10.2 & -- & 12.0 & 675.8 & -3.6 \\
\hline Right abutment & 93.4 & 97.3 & 695.0 & 679.4 & 682.5 & 1.8 & 20.6 & -- & 22.4 & 660.1 & -19.3 \\
\hline
\end{tabular}

1.Measured along the face of the most constricting side of the bridge.

2.Arbitrary datum for this study.

Table 2. Remaining footing/pile depth at abutments for the 500-year discharge at structure RYEGTH00050004 on Town Highway 5, crossing the Wells River, Ryegate, Vermont.

[VTAOT, Vermont Agency of Transportation; --, no data]

\begin{tabular}{|c|c|c|c|c|c|c|c|c|c|c|c|}
\hline Description & Station $^{1}$ & $\begin{array}{l}\text { VTAOT } \\
\text { minimum } \\
\text { bridge seat } \\
\text { elevation } \\
\text { (feet) }\end{array}$ & $\begin{array}{c}\text { Surveyed } \\
\text { minimum } \\
\text { low-chord } \\
\text { elevation } \\
\text { (feet) }\end{array}$ & $\begin{array}{c}\text { Bottom of } \\
\text { footing/pile } \\
\text { elevation } \\
\text { (feet) }\end{array}$ & $\begin{array}{c}\text { Channel } \\
\text { elevation at } \\
\text { abutment/ } \\
\text { pier }^{2} \\
\text { (feet) }\end{array}$ & $\begin{array}{l}\text { Contraction } \\
\text { scour depth } \\
\text { (feet) }\end{array}$ & $\begin{array}{l}\text { Abutment } \\
\text { scour } \\
\text { depth } \\
\text { (feet) }\end{array}$ & $\begin{array}{l}\text { Pier } \\
\text { scour } \\
\text { depth } \\
\text { (feet) }\end{array}$ & $\begin{array}{l}\text { Depth of } \\
\text { total scour } \\
\text { (feet) }\end{array}$ & $\begin{array}{c}\text { Elevation of } \\
\text { scour }^{2} \\
\text { (feet) }\end{array}$ & $\begin{array}{c}\text { Remaining } \\
\text { footing/pile } \\
\text { depth } \\
\text { (feet) }\end{array}$ \\
\hline \multicolumn{12}{|c|}{500 -yr. discharge is 7,210 cubic-feet per second } \\
\hline Left abutment & 0.0 & 98.6 & 696.2 & 679.4 & 687.8 & 2.6 & 11.8 & -- & 14.4 & 673.4 & -6.0 \\
\hline Right abutment & 93.4 & 97.3 & 695.0 & 679.4 & 682.5 & 2.6 & 22.6 & -- & 25.2 & 657.3 & -22.1 \\
\hline
\end{tabular}

1.Measured along the face of the most constricting side of the bridge.

2.Arbitrary datum for this study. 


\section{SELECTED REFERENCES}

Arcement, G.J., Jr., and Schneider, V.R., 1989, Guide for selecting Manning's roughness coefficients for natural channels and flood plains: U.S. Geological Survey Water-Supply Paper 2339, 38 p.

Barnes, H.H., Jr., 1967, Roughness characteristics of natural channels: U.S. Geological Survey Water-Supply Paper 1849,213 p.

Benson, M. A., 1962, Factors Influencing the Occurrence of Floods in a Humid Region of Diverse Terrain: U.S. Geological Survey WaterSupply Paper 1580-B, 64 p.

Brown, S.A. and Clyde, E.S., 1989, Design of riprap revetment: Federal Highway Administration Hydraulic Engineering Circular No. 11, Publication FHWA-IP-89-016, 156 p.

Federal Highway Administration, 1983, Runoff estimates for small watersheds and development of sound design: Federal Highway Administration Report FHWA-RD-77-158.

Federal Highway Administration, 1993, Stream Stability and Scour at Highway Bridges: Participant Workbook: Federal Highway Administration Report FHWA-HI-91-011.

Federal Emergency Management Agency, 1991, Flood Insurance Study, Town of Ryegate, Caledonia County, Vermont: Washington, D.C., June 17, 1991.

Froehlich, D.C., 1989, Local scour at bridge abutments in Ports, M.A., ed., Hydraulic Engineering--Proceedings of the 1989 National Conference on Hydraulic Engineering: New York, American Society of Civil Engineers, p. 13-18.

Hayes, D.C.,1993, Site selection and collection of bridge-scour data in Delaware, Maryland, and Virginia: U.S. Geological Survey WaterResources Investigation Report 93-4017, 23 p.

Interagency Advisory Committee on Water Data, 1982, Guidelines for determining flood flow frequency: U.S. Geological Survey, Bulletin 17B of the Hydrology Subcommittee, $190 \mathrm{p}$.

Johnson, C.G. and Tasker, G.D.,1974, Progress report on flood magnitude and frequency of Vermont streams: U.S. Geological Survey OpenFile Report 74-130, 37 p.

Lagasse, P.F., Schall, J.D., Johnson, F., Richardson, E.V., Chang, F., 1995, Stream Stability at Highway Structures: Federal Highway Administration Hydraulic Engineering Circular No. 20, Publication FHWA-IP-90-014, 144 p.

Laursen, E.M., 1960, Scour at bridge crossings: Journal of the Hydraulics Division, American Society of Civil Engineers, v. 86, no. HY2, p. 39-53.

Potter, W. D., 1957a, Peak rates of runoff in the Adirondack, White Mountains, and Maine woods area, Bureau of Public Roads

Potter, W. D., 1957b, Peak rates of runoff in the New England Hill and Lowland area, Bureau of Public Roads

Richardson, E.V. and Davis, S.R., 1995, Evaluating scour at bridges: Federal Highway Administration Hydraulic Engineering Circular No. 18, Publication FHWA-IP-90-017, 204 p.

Richardson, E.V., Simons, D.B., and Julien, P.Y., 1990, Highways in the river environment: Federal Highway Administration Publication FHWA-HI-90-016.

Ritter, D.F., 1984, Process Geomorphology: W.C. Brown Co., Debuque, Iowa, 603 p.

Shearman, J.O., 1990, User's manual for WSPRO--a computer model for water surface profile computations: Federal Highway Administration Publication FHWA-IP-89-027, 187 p.

Shearman, J.O., Kirby, W.H., Schneider, V.R., and Flippo, H.N., 1986, Bridge waterways analysis model; research report: Federal Highway Administration Publication FHWA-RD-86-108, 112 p.

Talbot, A.N., 1887, The determination of water-way for bridges and culverts.

U.S. Department of Transportation, 1993, Stream stability and scour at highway bridges, Participant Workbook: Federal Highway Administration Publication FHWA HI-91-011.

U.S. Geological Survey, 1973, Groton, Vermont 7.5 Minute Series quadrangle map: U.S. Geological Survey Topographic Maps, Scale $1: 24,000$.

U.S. Geological Survey, 1973, Woodsville, Vermont 7.5 Minute Series quadrangle map: U.S. Geological Survey Topographic Maps, Photorevised 1988, Scale 1:24,000. 


\section{APPENDIX A: \\ WSPRO INPUT FILE}




\section{WSPRO INPUT FILE}

GR

GR

GR

GR

$\mathrm{N}$

SA

*

XS

*

*

BR

GR

GR

GR

*

CD

$\mathrm{N}$

*

XR

GR

GR

GR

GR

*

AS

GR

GR

GR

GR

GR

$\mathrm{N}$

SA

HP 1 BRIDG

HP 2 BRIDG

HP 1 APPRO

HP 2 APPRO

*

HP 1 BRIDG

HP 2 BRIDG

$\mathrm{HP} 1 \mathrm{APPRO}$

HP 2 APPRO

*

EX
U.S. Geological Survey WSPRO Input File ryeg004.wsp Hydraulic analysis for structure RYEGTH00050004 Date: 13-JUN-97 Bridge 4 on Town Highway 5 over the Wells River, Ryegate, VT by MAI

$62930 \quad 552553551516 \quad 17 \quad 13 \quad 3 * \begin{array}{llllllllll}15 & 14 & 23 & 21 & 11 & 12 & 4 & 7 & 3\end{array}$

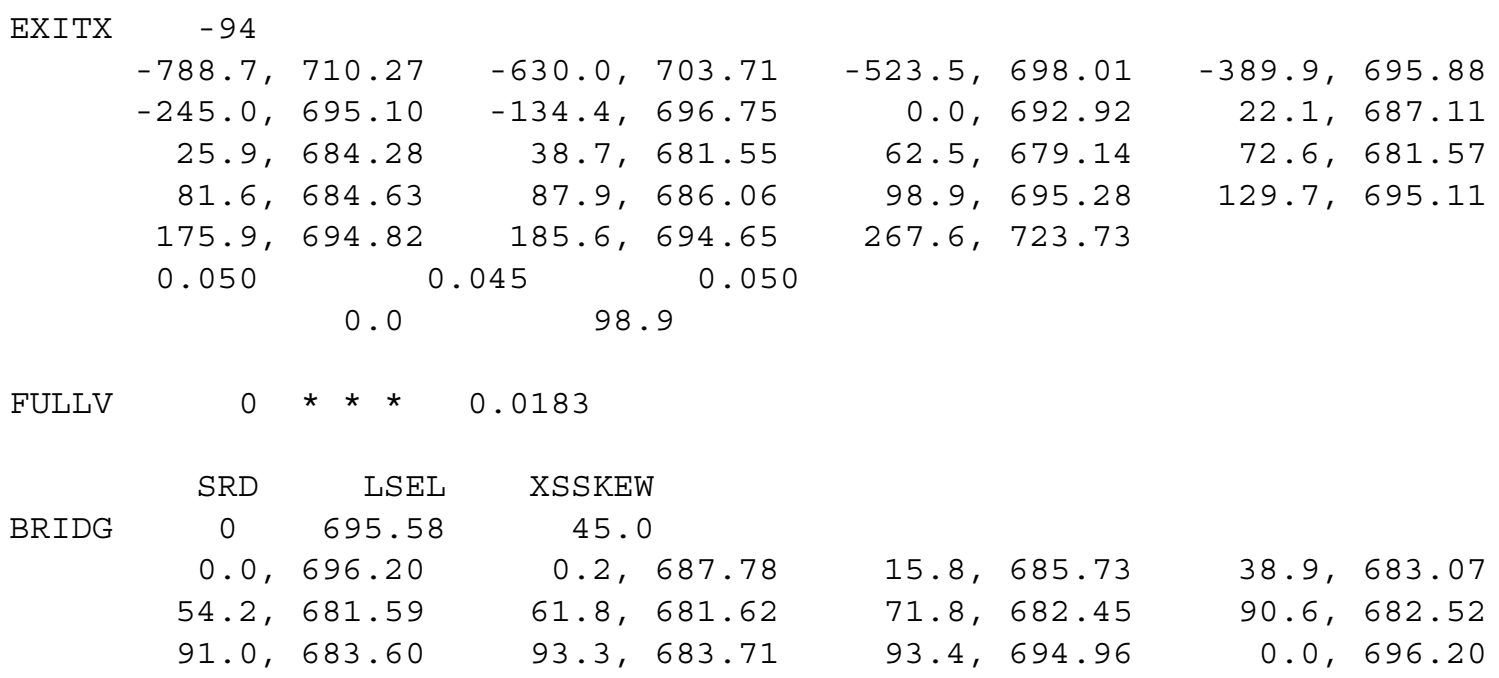

0.0

0.050

$129.7,695.11$

$\begin{array}{rr}15.8,685.73 & 38.9,683.07 \\ 71.8,682.45 & 90.6,682.52 \\ 93.4,694.96 & 0.0,696.20\end{array}$

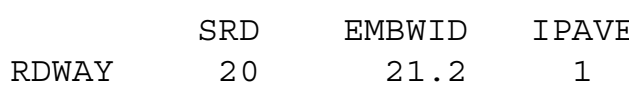




\section{APPENDIX B: \\ WSPRO OUTPUT FILE}




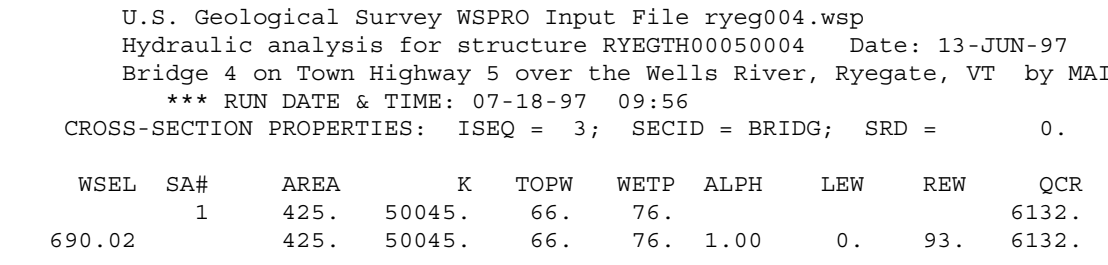

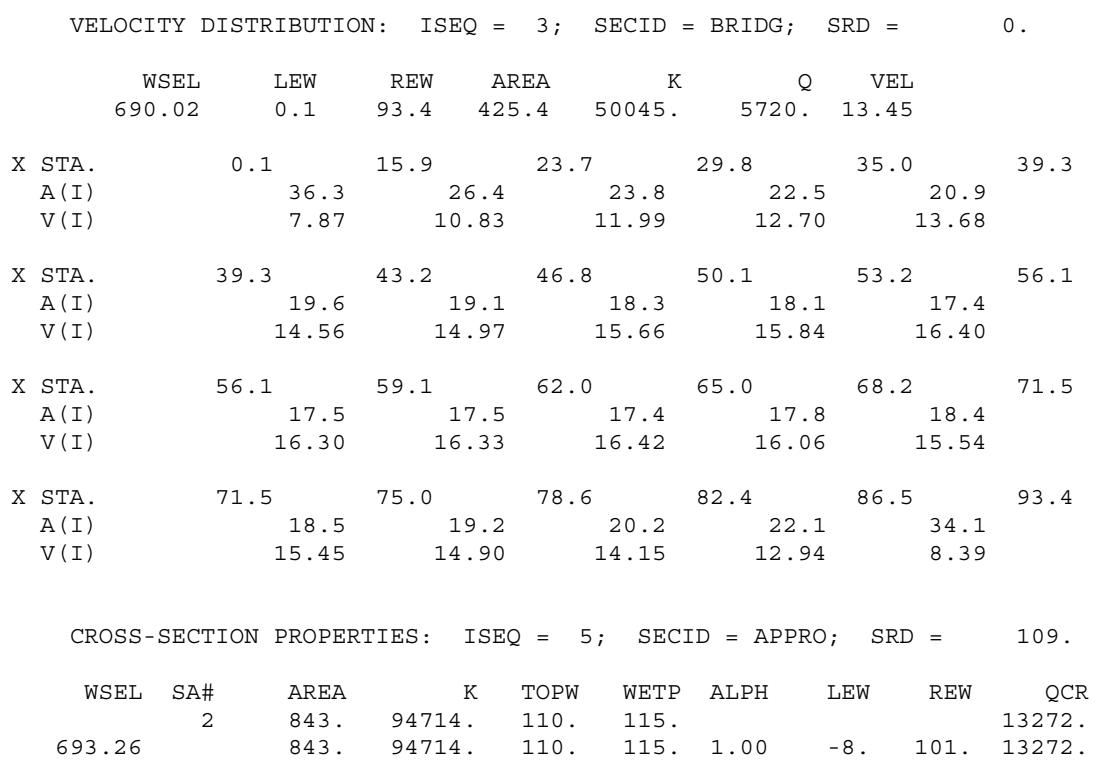

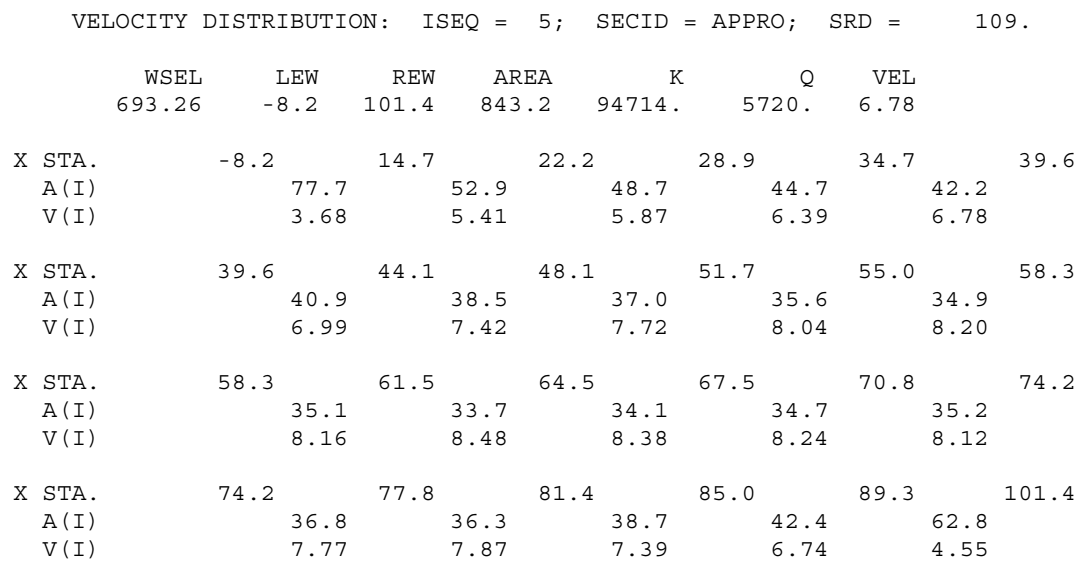


WSPRO OUTPUT FILE (continued)

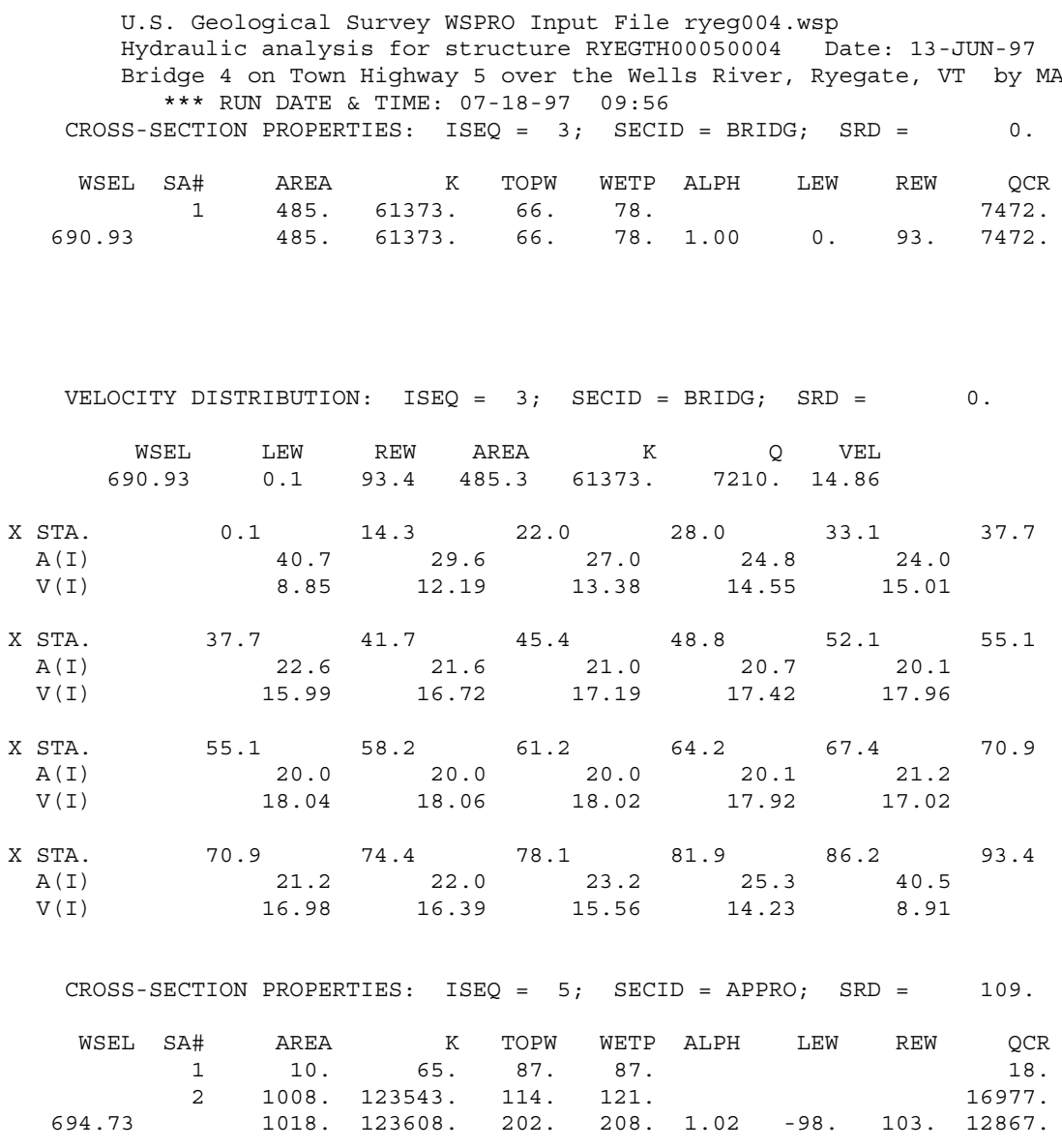

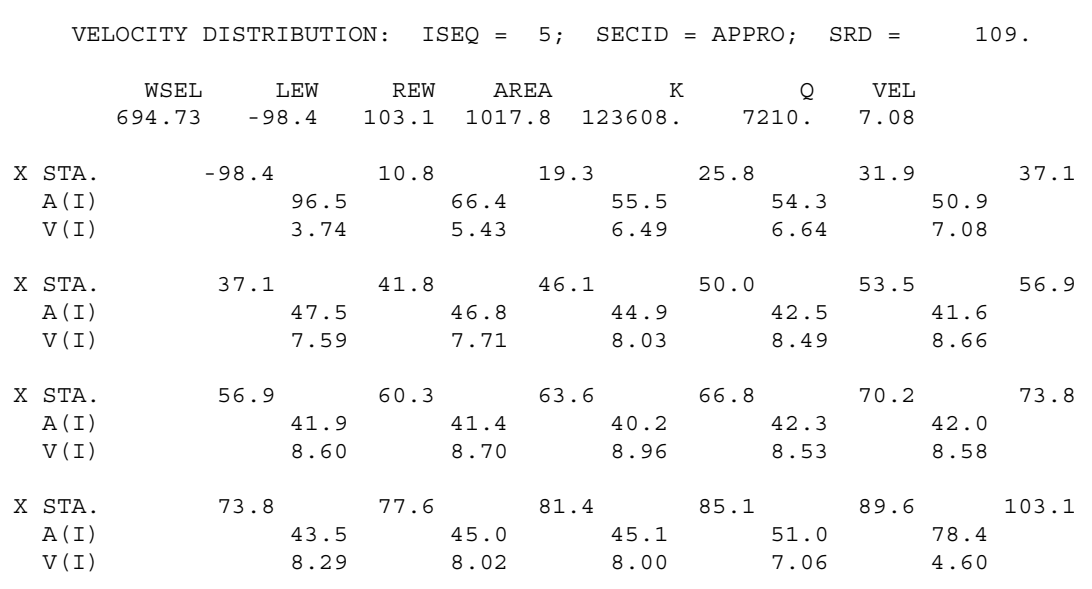


WSPRO OUTPUT FILE (continued)

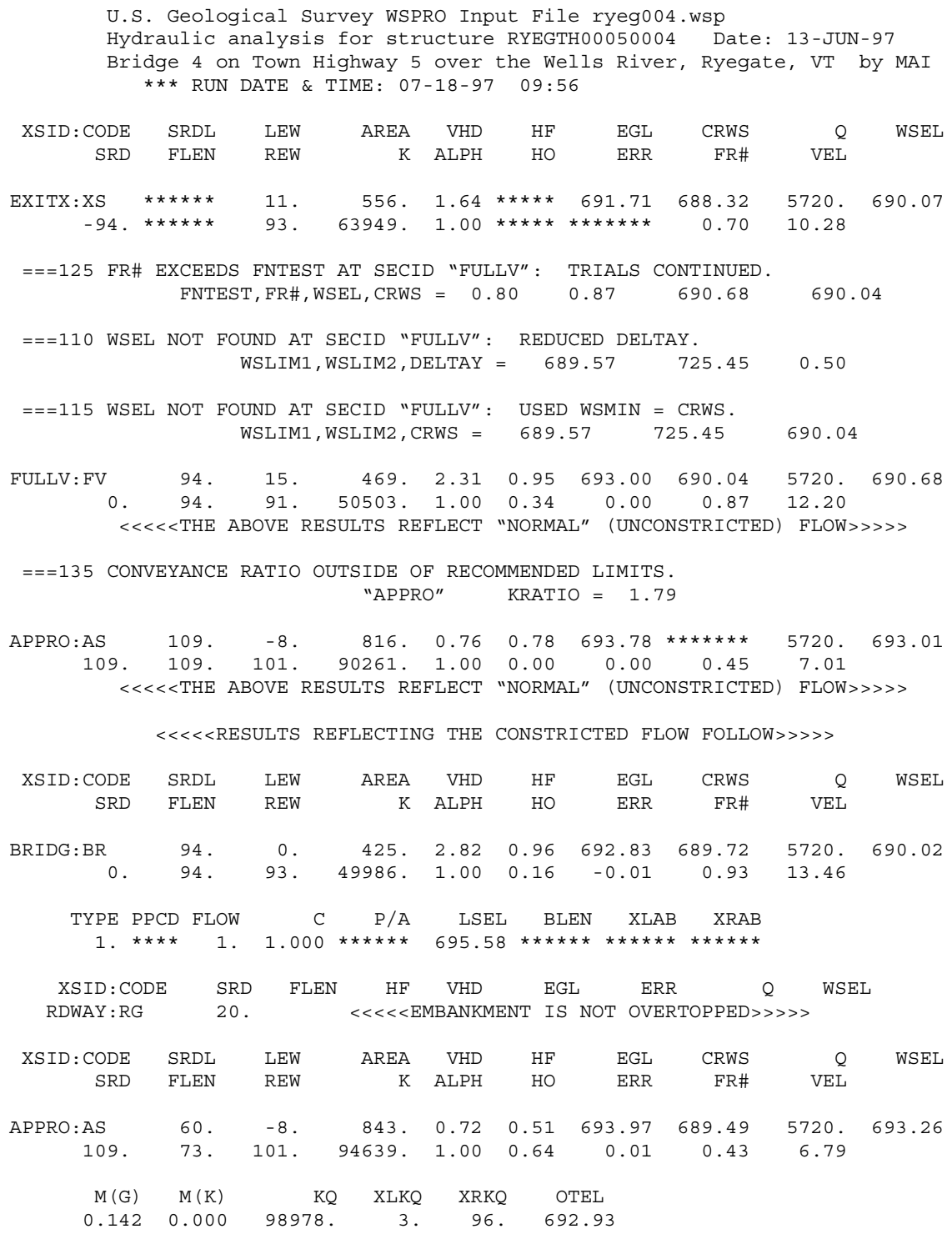


WSPRO OUTPUT FILE (continued)

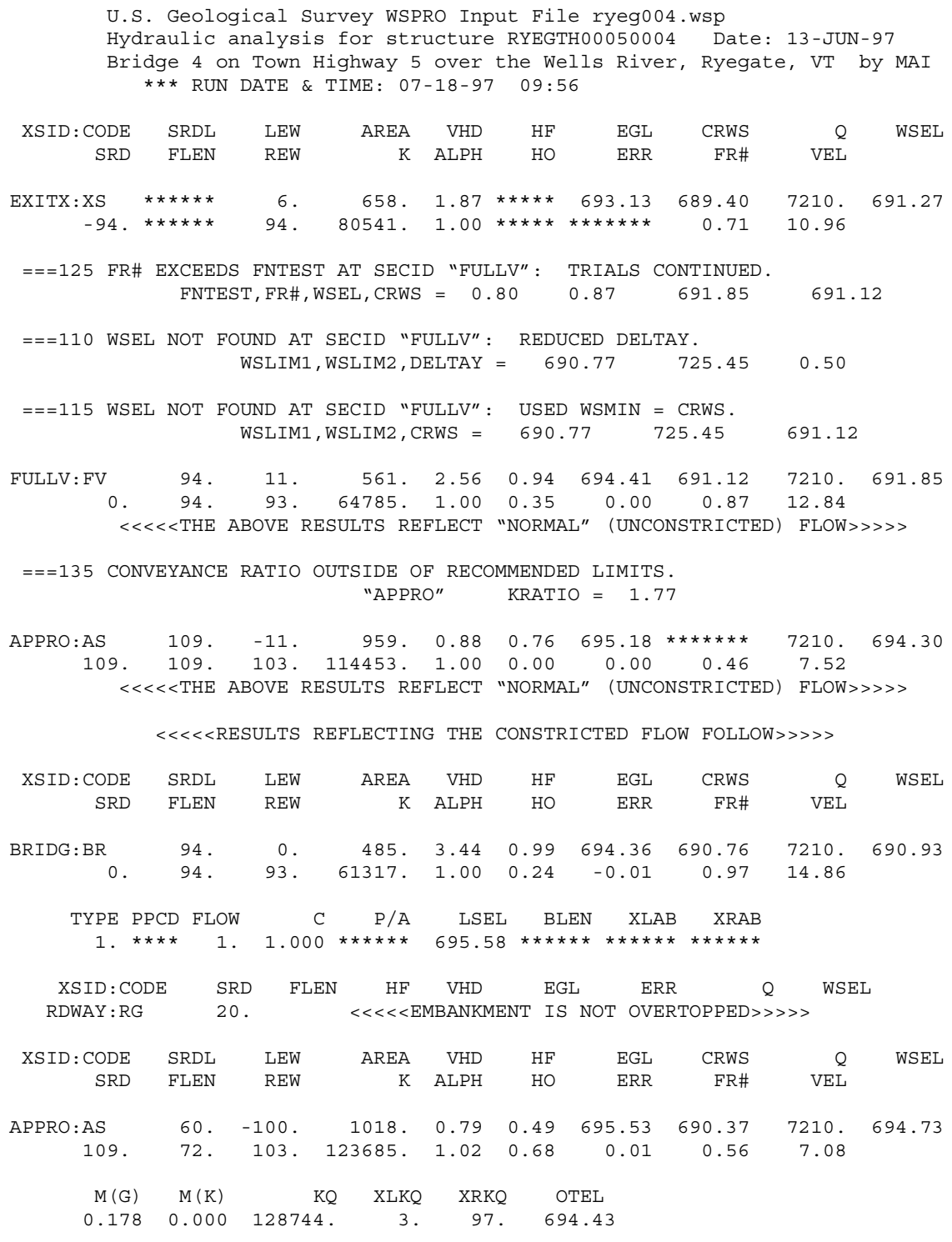




\section{APPENDIX C:}

\section{BED-MATERIAL PARTICLE-SIZE DISTRIBUTION}




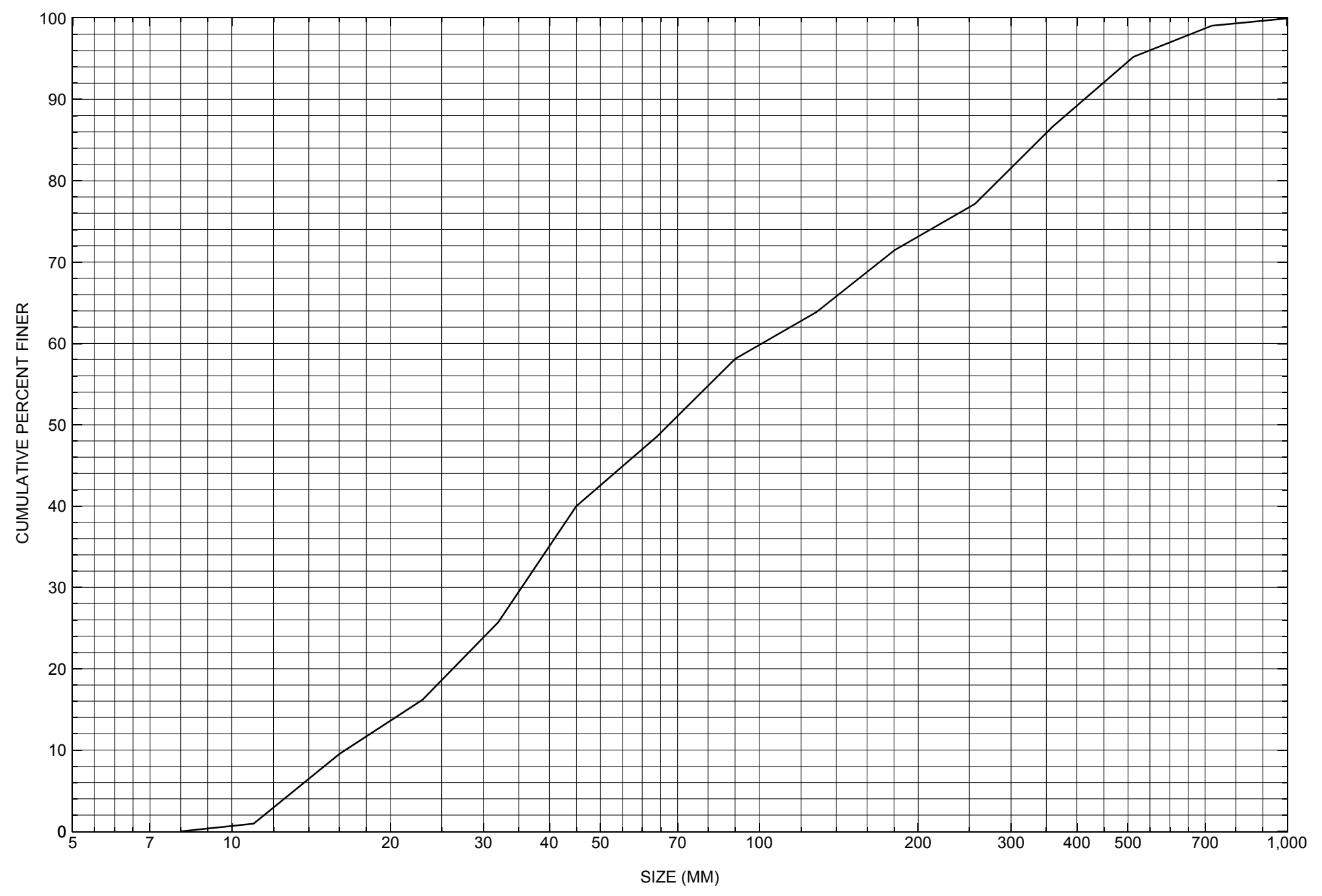

Appendix C. Bed material particle-size distribution for a pebble count in the channel approach of structure RYEGTH00050004, in Ryegate, Vermont. 


\section{APPENDIX D: \\ HISTORICAL DATA FORM}




\section{Structure Number RYEGTH00050004}

\section{General Location Descriptive}

Data collected by (First Initial, Full last name) M. IVANOFF

Date $(M M / D D / Y Y) \_\mathbf{0 3} / \underline{27} / \underline{95}$

Highway District Number (I - 2; nn) $\mathbf{0 7}$

Town (FIPS place code; I - 4; nnnnn) $\mathbf{6 1 5 2 5}$

Waterway (I - 6) WELLS RIVER

Route Number TH05

Topographic Map Woodsville

Latitude (I - 16; nnnn.n) $\mathbf{4 4 1 1 1}$
County (FIPS county code; I - 3; nnn)

Mile marker (I - 11; nnn.nnn) $\mathbf{0 0 0 0 0 0}$

Road Name (I - 7): -

Vicinity (I - 9) 0.2 MI JCT TH 5 + US 302

Hydrologic Unit Code: $\mathbf{0 1 0 8 0 1 0 3}$

Longitude (i - 17; nnnnn.n) 72051

\section{Select Federal Inventory Codes}

FHWA Structure Number (I - 8) $\mathbf{1 0 0 3 1 0 0 0 0 4 0 3 1 0}$

Maintenance responsibility $(I-21 ; n n) \quad \mathbf{0 3}$

Year built (I - 27; YYYY) 1929

Average daily traffic, ADT (I - 29; nnnnnn) $\mathbf{0 0 0 2 7 0}$

Year of ADT (I - 30; YY) $\mathbf{9 1}$

Opening skew to Roadway $(I-34 ; n n) \quad 45$

Operational status $(I-41 ; X) \quad \mathbf{A}$

Structure type (I - 43; nnn) $\mathbf{3 0 3}$

Approach span structure type (I - 44; nnn) $\mathbf{0 0 0}$

Number of spans (I - 45; nnn) $\mathbf{0 0 1}$

Number of approach spans (I - 46; nnnn) $\mathbf{0 0 0 0}$

Comments:

Structural inspection report of 6/7/93 indicates that the structure is a single span concrete deck type bridge with an asphalt surface. Abutments and wings are grouted stone blocks with concrete caps and backwalls. The caps have alligator cracks and leaks with spalling extending up to but not under each masonry plate except on the downstream right abutment. Right abutment and wings have an exposed concrete footing with some overall spalling. Some stone and boulder fill is present along left abutment, wings, and the up and downstream channel embankments. Some signs of erosion from past flooding are present along the embankments. (Continued, page 33) 


\section{Bridge Hydrologic Data}

Is there hydrologic data available? $\underline{\mathbf{N}}$ if No, type ctrl-n $h \quad$ VTAOT Drainage area $\left(m i^{2}\right)$ : -

Terrain character:

Stream character \& type: -

Streambed material:

Discharge Data (cfs):

$$
\begin{aligned}
& Q_{2.33}- \\
& Q_{50}-
\end{aligned}
$$

Record flood date $(M M / D D / Y Y)$ :

Estimated Discharge (cfs): Ice conditions (Heavy, Moderate, Light) : -

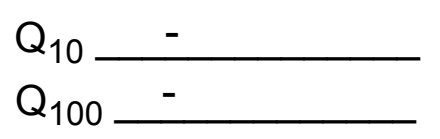

$$
\begin{aligned}
& Q_{25}- \\
& Q_{500}-
\end{aligned}
$$

Water surface elevation $(f t):-$

The stage increases to maximum highwater elevation (Rapidly, Not rapidly):

The stream response is (Flashy, Not flashy):

Describe any significant site conditions upstream or downstream that may influence the stream's stage: -

Watershed storage area (in percent): _ _ \%

The watershed storage area is: - (1-mainly at the headwaters; 2- uniformly distributed; 3-immediatly upstream oi the site)

Water Surface Elevation Estimates for Existing Structure:

\begin{tabular}{|l|l|l|l|l|l|}
\hline Peak discharge frequency & $Q_{2.33}$ & $Q_{10}$ & $Q_{25}$ & $Q_{50}$ & $Q_{100}$ \\
Water surface elevation (ft)) & - & - & - & - & - \\
Velocity (ft/sec) & - & - & - & - & - \\
\hline
\end{tabular}

Long term stream bed changes: -

Is the roadway overtopped below the $\mathrm{Q}_{100}$ ? (Yes, No, Unknown): $\mathbf{U}$ Frequency: Relief Elevation (ft): Discharge over roadway at $Q_{100}\left(f^{3} / \mathrm{sec}\right)$ :

Are there other structures nearby? (Yes, No, Unknown): $\underline{\mathbf{U}}$ Upstream distance (miles): Town: If No or Unknown, type ctrl-n os Highway No. : Structure No. : Year Built:

Clear span (ft): Clear Height $(f t)$ : Full Waterway $\left(f^{2}\right)$ : 
Downstream distance (miles): Town: Year Built:

Highway No. : Structure No. : Structure Type:

Clear span $(f t):$ Clear Height $(f t)$ : Full Waterway $\left(f t^{2}\right)$ :

Comments:

There is about 1 foot of channel scour along right abutment. Minor accumulation of debris. It was suggested, in the comments, to patch or replace the concrete caps on abutments.

\section{USGS Watershed Data}

Watershed Hydrographic Data

Drainage area $(D A) \stackrel{84.72}{\mathrm{mi}^{2}}$

Watershed storage (ST)

Bridge site elevation

Main channel length

680
2.6 680 17.34 $10 \%$ channel length elevation $\quad \mathbf{7 2 0}$

Main channel slope

(S) 53.59 $\mathrm{ft} / \mathrm{mi}$ $\%$ $\mathrm{mi}$

Lake/pond/swamp area

2.22 $\mathrm{mi}^{2}$

Headwater elevation $\mathbf{2 3 6 9} \mathrm{ft}$ $\mathrm{ft} \quad 85 \%$ channel length elevation $\mathrm{ft}$

Watershed Precipitation Data

Average site precipitation in Average headwater precipitation in

Maximum 2yr-24hr precipitation event $(124,2)$ in

Average seasonal snowfall (Sn) $\mathrm{ft}$ 


\section{Bridge Plan Data}

Are plans available? $\mathbf{Y}$ Project Number FR 4B If no, type ctrl-n pl Da ate iss

Minimum channel bed elevation: $\mathbf{8 7 . 5}$
Low superstructure elevation: USLAB $\mathbf{9 8 . 6 3}$ DSLAB $\mathbf{9 8 . 5 3}$ USRAB $\mathbf{9 7 . 3 3}$ DSRAB *
Benchmark location description:
Chiseled ' $X$ ' on top of stone of the upstream left wingwall at the corner of granite stone abutment wall, elevation 100.0.

Reference Point (MSL, Arbitrary, Other): Arbitrary _ Datum (NAD27, NAD83, Other): Arbitrary Foundation Type: 1 (1-Spreadfooting; 2-Pile; 3- Gravity; 4-Unknown)

If 1: Footing Thickness $\mathbf{4 . 3 3} \quad$ Footing bottom elevation: $\underline{\mathbf{8 3 . 5}}$

If 2: Pile Type: (1-Wood; 2-Steel or metal; 3-Concrete) Approximate pile driven length: -

If 3: Footing bottom elevation:

Is boring information available? $\mathbf{N}$ If no, type ctrl-n bi Number of borings taken: _-

Foundation Material Type: $\mathbf{3}$ (1-regolith, 2-bedrock, 3-unknown)

Briefly describe material at foundation bottom elevation or around piles:

NO FOUNDATION MATERIAL INFORMATION.

Comments:

Bottom of concrete footing of abutments planned at elevation 83.5 with a thickness of $4.33 \mathrm{ft}$. Note the footings may be exposed upon construction. Another point with elevation shown is on the top streamward edge of the right abutment on the upstream end where the concrete slope changes from horizontal to sloping downward, elevation $103.75 \mathrm{ft}$. At the above described location on the downstream end, elevation 102.81. 


\section{Cross-sectional Data}

Is cross-sectional data available? $\underline{\mathbf{N}}$ If no, type ctrl-n xs

Source (FEMA, VTAOT, Other)? -

Comments: NO CROSS SECTION INFORMATION

\begin{tabular}{|l|l|l|l|l|l|l|l|l|l|l|l|}
\hline Station & - & - & - & - & - & - & - & - & - & - & - \\
\hline Feature & - & - & - & - & - & - & - & - & - & - & - \\
\hline $\begin{array}{l}\text { Low chord } \\
\text { elevation }\end{array}$ & - & - & - & - & - & - & - & - & - & - & - \\
\hline $\begin{array}{l}\text { Bed } \\
\text { elevation }\end{array}$ & - & - & - & - & - & - & - & - & - & - & - \\
\hline $\begin{array}{l}\text { Low chord- } \\
\text { bed }\end{array}$ & - & - & - & - & - & - & - & - & - & - & - \\
\hline Station & - & - & - & - & - & - & - & - & - & - & - \\
\hline Feature & - & - & - & - & - & - & - & - & - & - & - \\
\hline $\begin{array}{l}\text { Low chord } \\
\text { elevation }\end{array}$ & - & - & - & - & - & - & - & - & - & - & - \\
\hline $\begin{array}{l}\text { Bed } \\
\text { elevation }\end{array}$ & - & - & - & - & - & - & - & - & - & - & - \\
\hline $\begin{array}{l}\text { Low chord- } \\
\text { bed }\end{array}$ & - & - & - & - & - & - & - & - & - & - & - \\
\hline
\end{tabular}

Source (FEMA, VTAOT, Other)?

Comments: NO CROSS SECTION INFORMATION

\begin{tabular}{|l|l|l|l|l|l|l|l|l|l|l|l|}
\hline Station & - & - & - & - & - & - & - & - & - & - & - \\
\hline Feature & - & - & - & - & - & - & - & - & - & - & - \\
\hline $\begin{array}{l}\text { Low chord } \\
\text { elevation }\end{array}$ & - & - & - & - & - & - & - & - & - & - & - \\
\hline $\begin{array}{l}\text { Bed } \\
\text { elevation }\end{array}$ & - & - & - & - & - & - & - & - & - & - & - \\
\hline $\begin{array}{l}\text { Low chord- } \\
\text { bed }\end{array}$ & - & - & - & - & - & - & - & - & - & - & - \\
\hline Station & - & - & - & - & - & - & - & - & - & - & - \\
\hline Feature & - & - & - & - & - & - & - & - & - & - & - \\
\hline $\begin{array}{l}\text { Low chord } \\
\text { elevation }\end{array}$ & - & - & - & - & - & - & - & - & - & - & - \\
\hline $\begin{array}{l}\text { Bed } \\
\text { elevation }\end{array}$ & - & - & - & - & - & - & - & - & - & - & \\
\hline $\begin{array}{l}\text { Low chord- } \\
\text { bed }\end{array}$ & - & - & - & - & - & - & - & - & - & - & \\
\hline
\end{tabular}




\section{APPENDIX E: \\ LEVEL I DATA FORM}


U. S. Geological Survey

Bridge Field Data Collection and Processing Form

Qa/Qc Check by: EW

Date: $\underline{\mathbf{0 3} / \mathbf{1 5} / \mathbf{9 6}}$

\section{Structure Number}

RYEGTH00050004 Date: $03 / 15 / 96$

\section{A. General Location Descriptive}

1. Data collected by (First Initial, Full last name) R. HAMMOND

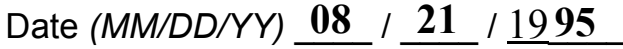

2. Highway District Number $\mathbf{0 7}$

County ESSEX 005

Waterway (I - 6) WELLS RIVER

Route Number TH5

3. Descriptive comments:

The site is located 0.2 miles from the junction with US 302
Mile marker -

Town RYEGATE 61525

Road Name -

Hydrologic Unit Code: $\mathbf{0 1 0 8 0 1 0 3}$

\section{B. Bridge Deck Observations}
4. Surface cover... LBUS 4
RBUS 6
LBDS 6
RBDS 5
Overall 6

(2b us, ds,lb,rb: 1- Urban; 2- Suburban; 3- Row crops; 4- Pasture; 5- Shrub- and brushland; 6- Forest; 7- Wetland)
5. Ambient water surface... US $\underline{2}$
UB 2
DS $\underline{2}$
(1- pool; 2- riffle)

6. Bridge structure type 1 (1- single span; 2- multiple span; 3- single arch; 4- multiple arch; 5-cylindrical culvert; 6- box culvert; or 7- other)
7. Bridge length 108 (feet)
Span length $\mathbf{1 0 0}$
(feet)
Bridge width 21.2 (feet)

\section{Road approach to bridge:}
8. LB 0
RB 1
( 0 even, 1- lower, 2- higher)
9. $\mathrm{LB}$
RB 1
(1- Paved, 2- Not paved)

10. Embankment slope (run / rise in feet / foot):

$$
\text { US left }
$$

2.0:1

US right

2.5:1

\begin{tabular}{|c|c|c|c|c|}
\hline & \multicolumn{2}{|c|}{ Protection } & \multirow{2}{*}{ 13.Erosion } & \multirow{2}{*}{ 14.Severity } \\
\hline & 11.Type & 12.Cond. & & \\
\hline LBUS & 0 & - & 2 & 1 \\
\hline RBUS & $\mathbf{0}$ & - & 2 & $\mathbf{0}$ \\
\hline RBDS & 2 & 1 & 2 & 1 \\
\hline LBDS & 1 & 1 & 2 & $\mathbf{0}$ \\
\hline
\end{tabular}

Bank protection types: 0- none; 1- < 12 inches;

2- < 36 inches; 3- < 48 inches;

4- $<60$ inches; 5- wall / artificial levee

Bank protection conditions: 1- good; 2- slumped;

3- eroded; 4- failed

Erosion: 0 - none; 1- channel erosion; 2-

road wash; 3- both; 4- other

Erosion Severity: 0 - none; 1- slight; 2- moderate;

\section{Channel approach to bridge (BF):}

15. Angle of approach: $\mathbf{2 0}$

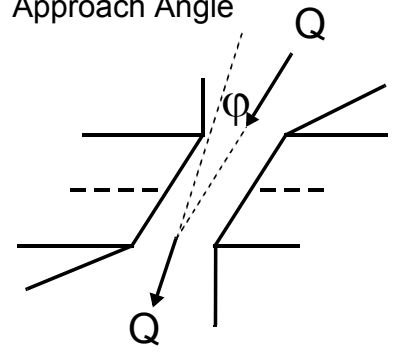

17. Channel impact zone 1:

Where? RB (LB, RB)

Range? 30 feet $\underline{\text { US }}$

Channel impact zone 2:

Where? LB (LB, RB)

Range? 10 feet DS

Impact Severity: 0- none to very slight; 1- Slight; 2- Moderate; 3- Severe
16. Bridge skew: $\mathbf{5 0}$ Bridge Skew Angle

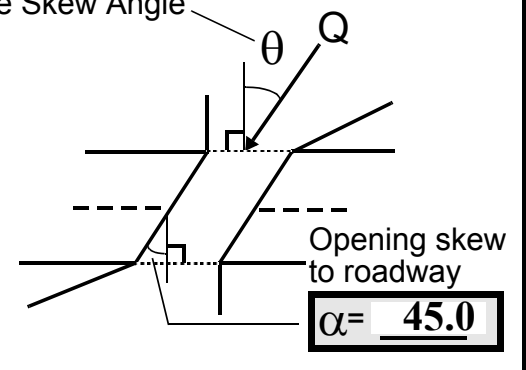

\section{Exist? $\mathbf{Y}(Y$ or $N)$}

Severity 1

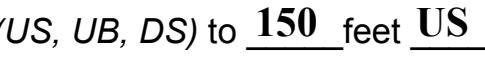

Exist? $\underline{\mathbf{Y}}(\mathrm{Y}$ or $N)$

Severity 2

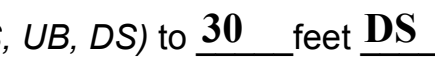


18. Bridge Type: 1a

1a- Vertical abutments with wingwalls

1 b- Vertical abutments without wingwalls

2- Vertical abutments and wingwalls, sloping embankment

Wingwalls parallel to abut. face

3- Spill through abutments

4- Sloping embankment, vertical wingwalls and abutments

Wingwall angle less than $90^{\circ}$.

19. Bridge Deck Comments (surface cover variations, measured bridge and span lengths, bridge type variations, approach overflow width, etc.)

\#7: The bridge dimension values are from the VTAOT. The measured values were: bridge length of 108 feet; bridge span at 97 feet; bridge width of 21.2 feet between the steel braces.

\#18: The slope of the wingwalls end above the low cord.

\section{Upstream Channel Assessment}

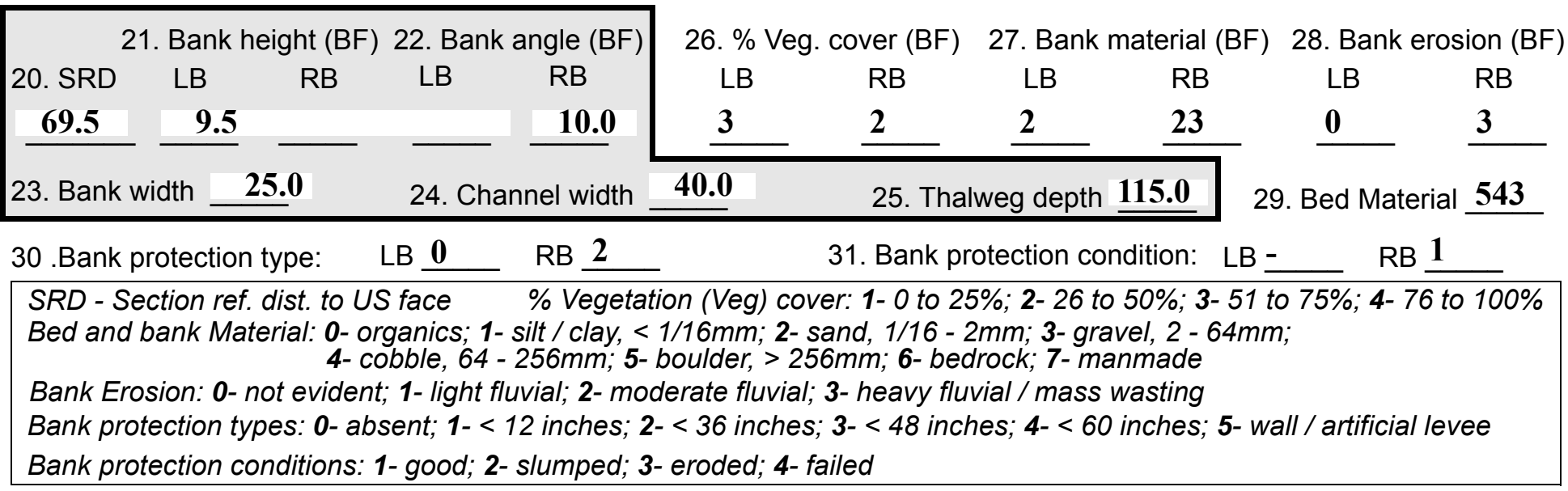

32. Comments (bank material variation, minor inflows, protection extent, etc.):

\#30: The right bank protection is from 120 feet to 300 feet upstream with large boulders placed to protect highway 302 embankment. 

feet $\underline{\mathbf{U S}}$ (US, UB, DS) positioned $\mathbf{0}$ $\%$ LB to 80 $\% R B$

\section{Material: 54}

38. Point or side bar comments (Circle Point or Side; Note additional bars, material variation, status, etc.):

The point bar includes a soil capped area near the left bank. There are some small trees on top of the bar.

39. Is a cut-bank present? $\mathbf{Y}$ (Y or if $N$ type ctrl-n cb)

41. Mid-bank distance: $\mathbf{9 0}$

42. Cut bank extent: 30

40. Where? $\mathbf{R B} \quad(L B$ or $R B)$

43. Bank damage: 3 (1- eroded and/or creep; 2- slip failure; 3- block failure)

44. Cut bank comments (eg. additional cut banks, protection condition, etc.):

Channel migrates towards the right bank and cuts into a steep bank.

Large diameter trees ( $>6$ inches) are also a part of block slump

\section{Is channel scour present? $\mathbf{Y}$ ( $Y$ or if $N$ type ctrl-n cs) $\quad$ 46. Mid-scour distance: 25 \\ 47. Scour dimensions: Length $\underline{\mathbf{2 5}}$ Width $\underline{\mathbf{8}}$ Depth: $\underline{\mathbf{2 . 5}}$ Position $\underline{\mathbf{8 0}} \%$ LB to $\underline{\mathbf{9 0}} \%$ RB}

48. Scour comments (eg. additional scour areas, local scouring process, etc.):

The scour is in the channel next to two large boulders (each with 2 meter diameters)

49. Are there major confluences? $\mathbf{N}$

51. Confluence 1: Distance Confluence 2: Distance -
52. Enters on -

Enters on -
( $Y$ or if $N$ type ctrl-n $m c$ ) ( $L B$ or $R B)$ (LB or $R B)$

54. Confluence comments (eg. confluence name):

\section{NO MAJOR CONFLUENCES}

\section{Under Bridge Channel Assessment}

55. Channel restraint (BF)? LB 2

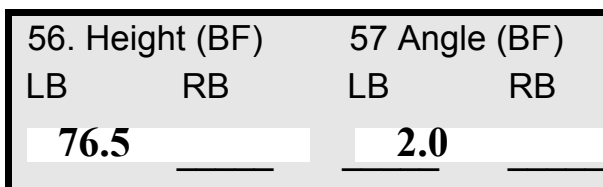
(1- natural bank; 2- abutment; 3- artificial levee)

58. Bank width (BF) -

59. Channel width -

\begin{tabular}{lclc} 
61. Material (BF) & \multicolumn{3}{l}{ 62. Erosion (BF) } \\
LB & RB & LB & RB \\
$\mathbf{2}$ & $\mathbf{7}$ & $\mathbf{7}$ & $\mathbf{0}$ \\
\hline
\end{tabular}

60. Thalweg depth $\lcm{90.0}$ (1-perennial; 2- ephemeral) (1-perennial; 2- ephemeral)

Bed and bank Material: 0- organics; 1- silt / clay, < 1/16mm; 2- sand, 1/16 - 2mm; 3- gravel, 2 - 64mm; 4- cobble, 64 - 256mm; 5- boulder, > 256mm; 6- bedrock; 7- manmade

Bank Erosion: 0- not evident; 1- light fluvial; 2- moderate fluvial; 3- heavy fluvial / mass wasting

64. Comments (bank material variation, minor inflows, protection extent, etc.):

543 
65. Debris and Ice Is there debris accumulation?

(Yor $N)$ 66. Where? $\underline{Y}$

(1- Upstream; 2- At bridge; 3- Both)

67. Debris Potential 2 (1-Low; 2-Moderate; 3- High)

68. Capture Efficiency 1

(1-Low; 2- Moderate; 3- High)

69. Is there evidence of ice build-up? 1 (Y or $N)$

Ice Blockage Potential $\mathbf{N}$

(1- Low; 2- Moderate; 3- High)

70. Debris and Ice Comments:

1

There is debris caught on old pilings 3 feet streamside of RB footing

\begin{tabular}{|l|c|c|c|c|c|c|c|c|}
\hline Abutments & $\begin{array}{c}\text { 71. Attack } \\
\angle \mathrm{BF})\end{array}$ & $\begin{array}{c}\text { 72. Slope } \\
(\mathrm{Qmax})\end{array}$ & $\begin{array}{c}\text { 73. Toe } \\
\text { loc. (BF) }\end{array}$ & $\begin{array}{c}\text { 74. Scour } \\
\text { Condition }\end{array}$ & $\begin{array}{c}\text { 75. Scour } \\
\text { depth }\end{array}$ & $\begin{array}{c}\text { 76. Exposure } \\
\text { depth }\end{array}$ & 77. Material & 78. Length \\
\hline LABUT & & $\mathbf{1 0}$ & $\mathbf{9 0}$ & $\mathbf{2}$ & $\mathbf{0}$ & - & $\mathbf{0}$ & $\mathbf{9 0 . 0}$ \\
\hline RABUT & $\mathbf{2}$ & $\mathbf{0}$ & $\mathbf{9 0}$ & & & $\mathbf{2}$ & $\mathbf{2}$ & $\mathbf{6 6 . 0}$ \\
\hline
\end{tabular}

Pushed: $L B$ or RB

Toe Location (Loc.): 0- even, 1- set back, 2- protrudes

Scour cond.: 0- not evident; 1- evident (comment); 2- footing exposed; 3-undermined footing; 4- piling exposed; 5- settled; 6- failed

Materials: 1- Concrete; 2- Stone masonry or drywall; 3- steel or metal; 4- wood

79. Abutment comments (eg. undermined penetration, unusual scour processes, debris, etc.):

80. Wingwalls:

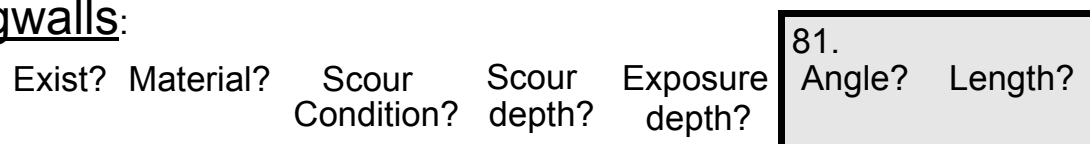

USLWW:

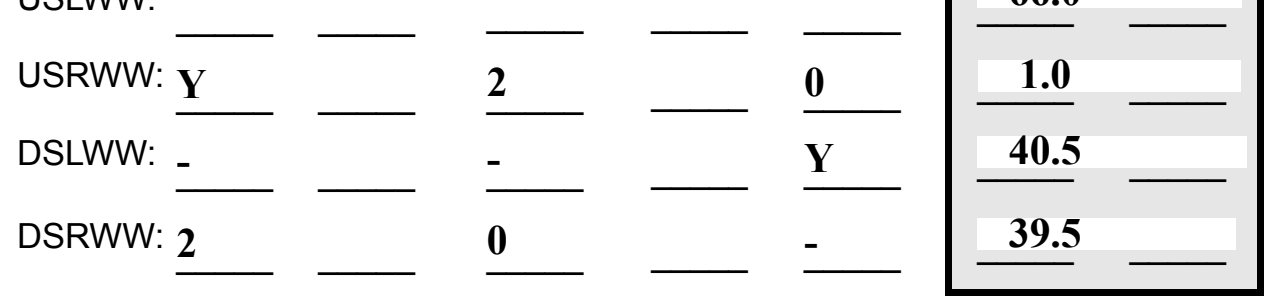

Wingwall materials: 1- Concrete; 2- Stone masonry or drywall; 3- steel or metal; 4- wood

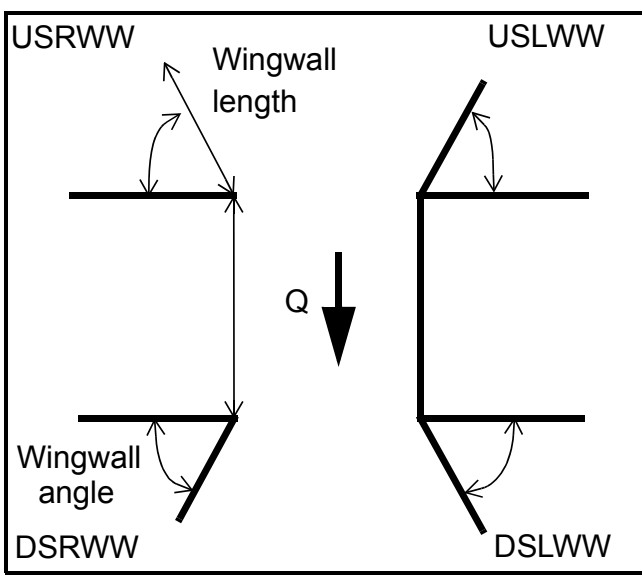

82. Bank / Bridge Protection:

\begin{tabular}{|l|l|l|l|l|l|l|l|c|}
\hline Location & USLWW & USRWW & LABUT & RABUT & LB & RB & DSLWW & DSRWW \\
\hline Type & - & $\mathbf{0}$ & $\mathbf{Y}$ & $\mathbf{0}$ & - & $\mathbf{1}$ & - & - \\
\hline Condition & $\mathbf{Y}$ & - & $\mathbf{2}$ & $\mathbf{2}$ & - & $\mathbf{1}$ & - & - \\
\hline Extent & $\mathbf{2}$ & - & $\mathbf{2}$ & $\mathbf{0}$ & $\mathbf{2}$ & $\mathbf{0}$ & $\mathbf{0}$ & - \\
\hline
\end{tabular}

Bank / Bridge protection types: 0- absent; 1- < 12 inches; 2- < 36 inches; 3- < 48 inches; 4- < 60 inches; 
83. Wingwall and protection comments (eg. undermined penetration, unusual scour processes, etc.):

-
-
-
-
-
0
-
-
2
1
3

\section{Piers:}

84. Are there piers? Th (Y or if N type ctrl-n pr)

\begin{tabular}{|l|l|l|l|l|l|l|l|}
\hline \multirow{2}{*}{$\begin{array}{l}85 . \\
\text { Pier no. }\end{array}$} & \multicolumn{3}{|c|}{ width (w) feet } & \multicolumn{3}{c|}{ elevation (e) feet } \\
\cline { 2 - 8 } & w1 & w2 & w3 & e@w1 & e@w2 & e@w3 \\
\hline Pier 1 & & & & $\mathbf{1 0 . 0}$ & $\mathbf{1 9 . 0}$ & $\mathbf{1 0 0 . 0}$ \\
\hline Pier 2 & & & & $\mathbf{1 5 . 5}$ & $\mathbf{1 4 0 . 0}$ & $\mathbf{1 5 . 0}$ \\
\hline Pier 3 & & & - & $\mathbf{1 5 . 0}$ & $\mathbf{2 9 . 5}$ & - \\
\hline Pier 4 & - & - & - & - & - & - \\
Nyyyy
\end{tabular}

\begin{tabular}{|l|l|l|l|l|}
\hline Level 1 Pier Descr. & \multicolumn{1}{|c|}{1} & \multicolumn{1}{|c|}{2} & 3 & \multicolumn{1}{|c|}{} \\
\hline 86. Location (BF) & e pro- & of scat- & & - \\
\hline 87. Type & tec- & tered & & - \\
\hline 88. Material & tion & type & & - \\
\hline 89. Shape & for & $\mathbf{1}$ & & - \\
\hline 90. Inclined? & the & and & & - \\
\hline 91. Attack $\angle$ (BF) & upst & $\mathbf{2}$ & N & - \\
\hline 92. Pushed & ream & rock. & - & - \\
\hline 93. Length (feet) & - & - & - & - \\
\hline 94. \# of piles & left & & - & - \\
\hline 95. Cross-members & wing & & - & - \\
\hline 96. Scour Condition & wall & & - & - \\
\hline 97. Scour depth & con- & & - & - \\
\hline 98. Exposure depth & sist & & - & - \\
\hline
\end{tabular}

LFP, LTB, LB, MCL, MCM, MCR, RB, RTB, RFP

1- Solid pier, 2-column, 3- bent

1-Wood; 2- concrete; 3- metal; 4- stone

1- Round; 2- Square; 3- Pointed

Y-yes; $N$ - no

$L B$ or $R B$

0- none; 1- laterals; 2- diagonals; 3- both

0- not evident; 1- evident (comment);

2- footing exposed; 3- piling exposed;

4- undermined footing; 5- settled; 6- failed 
99. Pier comments (eg. undermined penetration, protection and protection extent, unusual scour processes, etc.):

-
-
-
-
-
-
-
-
-
-

100.

\section{E. Downstream Channel Assessment}

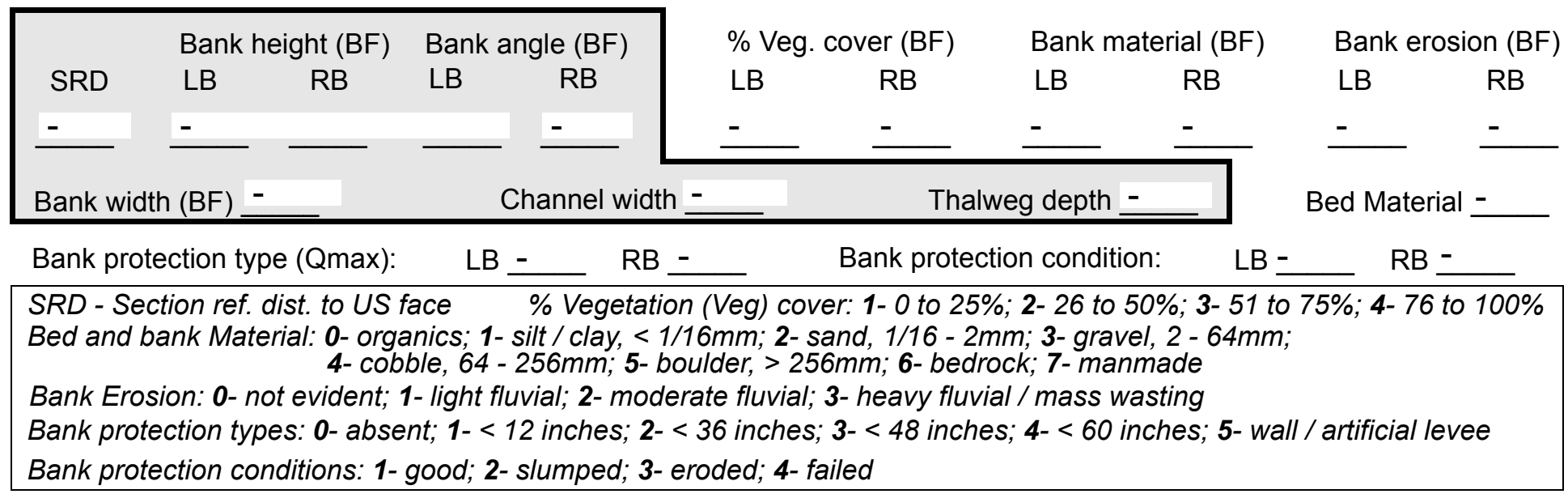

Comments (eg. bank material variation, minor inflows, protection extent, etc.):

-
-
-
-
-
-
-
-

NO PIERS

101. Is a drop structure present? ( $Y$ or $N$, if $N$ type ctrl-n ds)

102. Distance: - feet

103. Drop: __ feet 104. Structure material: (1- steel sheet pile; 2- wood pile; 3- concrete; 4- other)

105. Drop structure comments (eg. downstream scour depth): 
Point bar extent: $\underline{\mathbf{2}}$ feet $\underline{\mathbf{2 3}}$ (US, UB, DS) to $\underline{1}$ feet $\underline{\mathbf{1}}$ (US, UB, DS) positioned $\underline{\mathbf{T h}} \%$ LB to $\underline{\mathbf{e}} \%$ RB Material: left

Point or side bar comments (Circle Point or Side; note additional bars, material variation, status, etc.):

bank material consist of fill base for old railroad bed (quarry debris) which runs adjacent to the channel on the left bank downstream.

Is a cut-bank present?

Cut bank extent: feet (Y or if $N$ type ctrl-n cb) Where? (LB or $R B)$ feet (US, UB, DS)

Bank damage: (US, UB, DS) to (1- eroded and/or creep; 2- slip failure; 3- block failure)

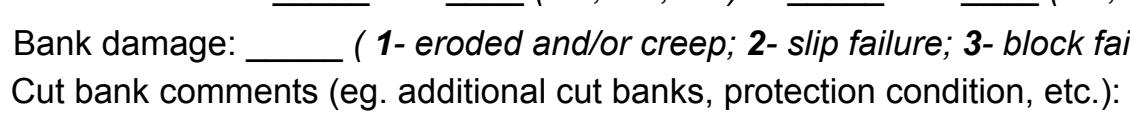

$\mathbf{N}$

Is channel scour present? ( $Y$ or if $N$ type ctrl-n cs)

Mid-scour distance: NO

\section{Are there major confluences?}

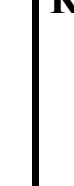

How many?

Type 20 (1- perennial; 2- ephemeral)

Scour comments (eg. additional scour areas, local scouring process, etc.): ( $Y$ or if $N$ type ctrl-n $m c)$

\section{F. Geomorphic Channel Assessment}

$\begin{array}{ll}\text { 107. Stage of reach evolution } \mathbf{1 0 0} & \mathbf{1} \text { - Constructed } \\ \mathbf{2}-\text { Stable } & \mathbf{3} \text { - Aggraded } \\ \mathbf{4} \text { - Degraded } & \mathbf{5} \text { - Laterally unstable } \\ \mathbf{6} \text { - Vertically and laterally unstable }\end{array}$

\section{Enters on $\underline{160}$ (LB or RB) Enters on $\underline{\mathbf{D S}}$ (LB or RB)}

Type $\underline{\mathbf{2 5 0}}$
DS

\author{
1- Constructed \\ 2- Stable \\ 5- Laterally unstable
6- Vertically and laterally unstable
}

0
uence comments (eg. confluence name):

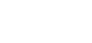


108. Evolution comments (Channel evolution not considering bridge effects; See HEC-20, Figure 1 for geomorphic descriptors):

543

Y

LB

20

0

DS

30

DS

1 


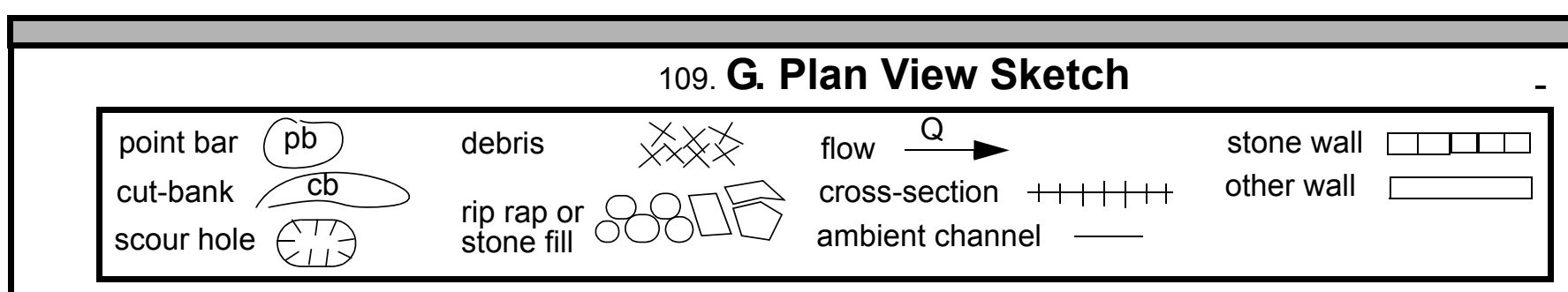


APPENDIX F:

SCOUR COMPUTATIONS 


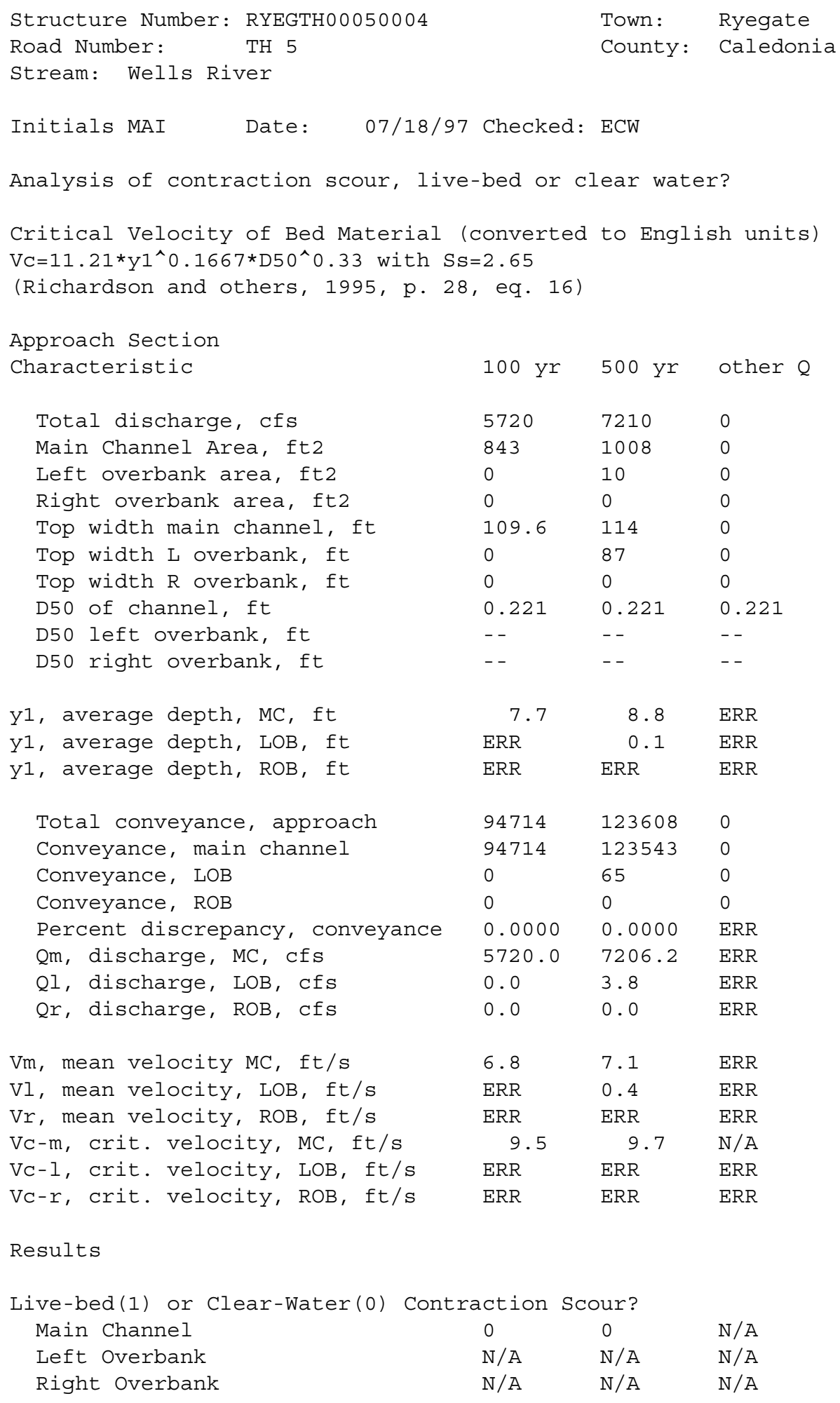


Clear Water Contraction Scour in MAIN CHANNEL

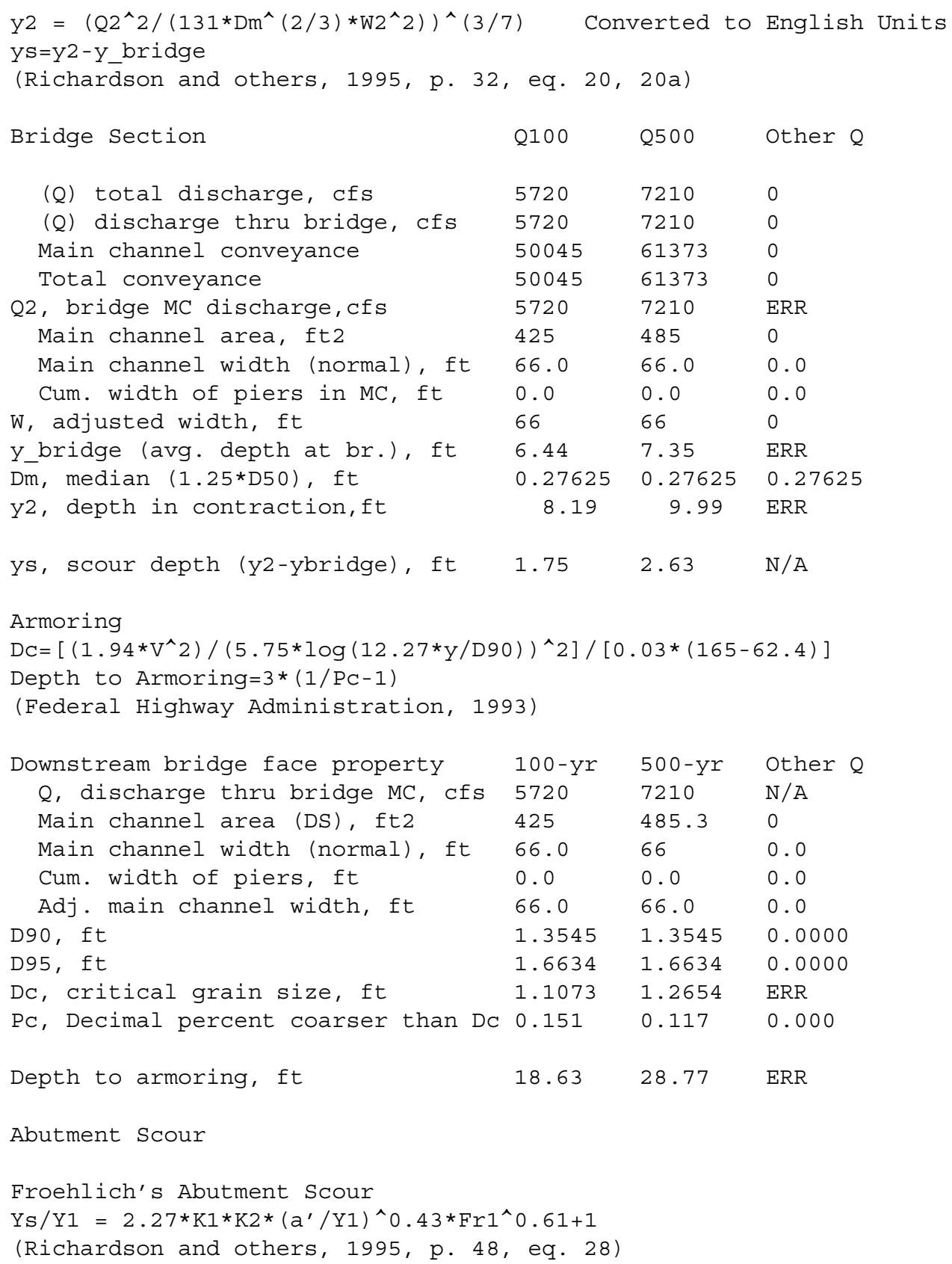




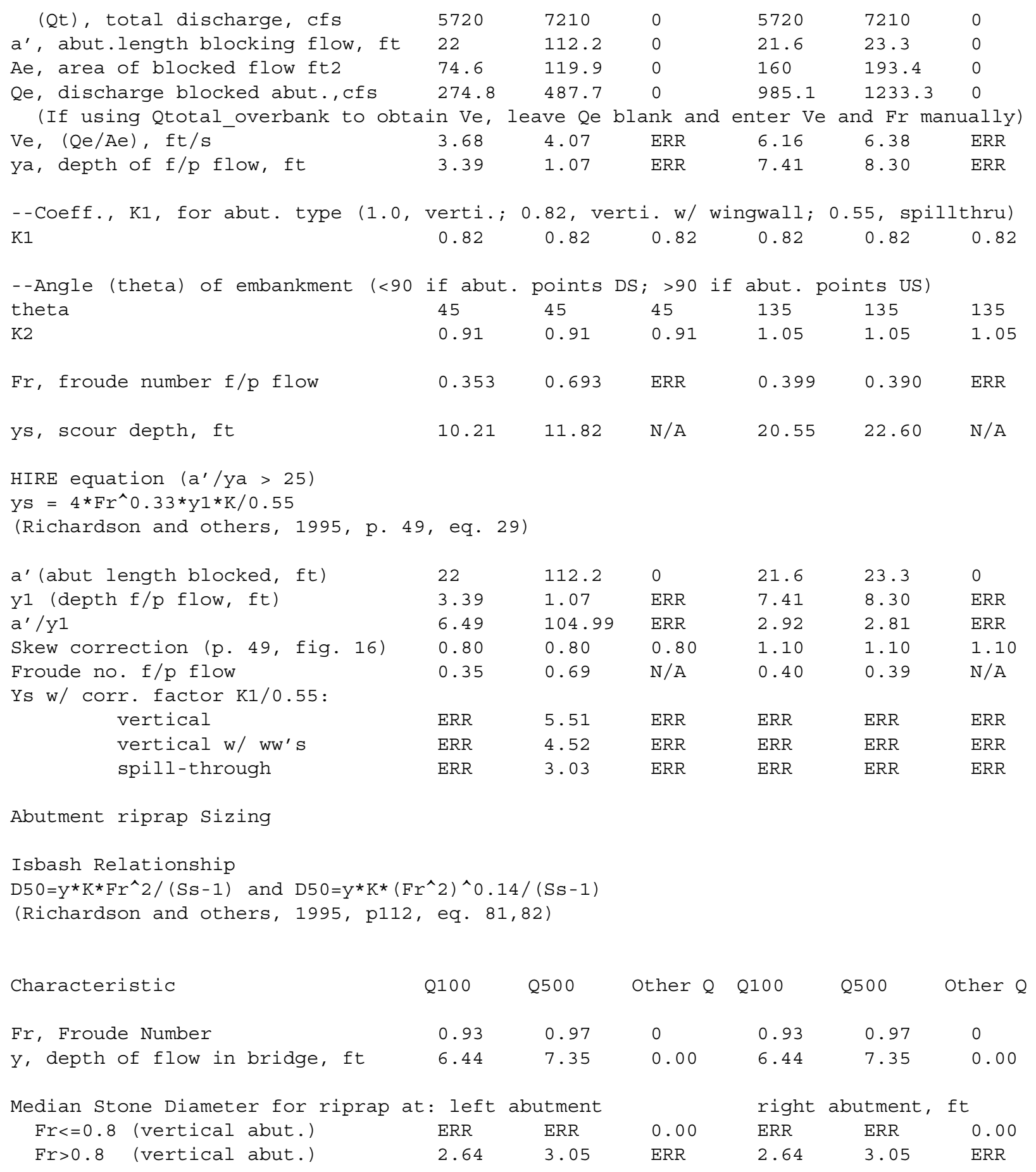


